NBER WORKING PAPER SERIES

\title{
IS TRADE GOOD OR BAD FOR THE ENVIRONMENT? SORTING OUT THE CAUSALITY
}

\author{
Jeffrey A. Frankel \\ Andrew K. Rose \\ Working Paper 9201 \\ http://www.nber.org/papers/w9201
NATIONAL BUREAU OF ECONOMIC RESEARCH
1050 Massachusetts Avenue
Cambridge, MA 02138
September 2002

The authors would like to thank for useful comments Ian Bowles, Bill Clark, Dan Esty, Arik Levinson, Joe Nye, Edward Parson, Rob Stavins, M. Scott Taylor, Geoffrey Williamson and other participants in the NBER Environmental Economics program meeting and the Environmental Economics, KSG Faculty Lunch and International Economics seminars, all three at Harvard. Frankel would also like to acknowledge support from the Savitz Family Fund for Environmental and Natural Resource Policy. The views expressed herein are those of the authors and not necessarily those of the National Bureau of Economic Research.

(C) 2002 by Jeffrey A. Frankel and Andrew K. Rose. All rights reserved. Short sections of text, not to exceed two paragraphs, may be quoted without explicit permission provided that full credit, including $\mathbb{C}$ notice, is given to the source. 
Is Trade Good or Bad for the Environment? Sorting Out the Causality

Jeffrey A. Frankel and Andrew K. Rose

NBER Working Paper No. 9201

September 2002

JEL No. Q2, F1

\section{$\underline{\text { ABSTRACT }}$}

What is the effect of trade on a country's environment, for a given level of GDP? Some have observed an apparent positive correlation between openness to trade and measures of environmental quality. But this could be due to endogeneity of trade, rather than causality. This paper uses exogenous determinants of trade - geographical variables from the gravity model - as instruments to isolate the effect of openness. The finding is that trade may indeed have a beneficial effect on three measures of air pollution. Statistical significance is lacking for Particulate Matter, but is moderate for $\mathrm{NO} 2$, and high for $\mathrm{SO}$. Results for broader environmental measures are not as encouraging, but one can at least say that there is little evidence that trade has the detrimental effect on the environment that the race-to-the-bottom theory would lead one to expect. The larger effect appears to come via income itself: our results generally support the environmental Kuznets curve, which says that growth harms the environment at low levels of income and helps at high levels, and to support the proposition that openness to trade accelerates the growth process.

Jeffrey A. Frankel

Kennedy School of Government Harvard University, 79 JFK Street

Cambridge MA 02138-5801

and NBER jeffrey_frankel@harvard.edu http://www.ksg.harvard.edu/fs/jfrankel
Andrew K. Rose

Haas School of Business

University of California

Berkeley, CA 94720-1900

and NBER

arose@haas.berkeley.edu

http://haas.berkeley.edu/ arose 


\title{
Is Trade Good or Bad for the Environment? Sorting Out the Causality
}

\author{
Jeffrey Frankel and Andrew Rose
}

Opponents of globalization usually do not argue that trade is bad for economic growth, as measured by GDP. Rather they fear adverse effects on such "non-economic" objectives as environmental quality. ${ }^{1} \quad$ If the term globalization is meant to capture the totality of industrialization, then there is little question that, at least at the early stages of economic development, environmental degradation is a consequence. If the human species still consisted of a few thousand hunter-gatherers, for example, man-made pollution would be close to zero. This is not the interesting question, however. The interesting questions are (1) whether economic growth eventually brings environmental improvement and (2) whether cross-border integration helps or hurts in this process. That first question is the much-studied environmental Kuznets curve, while the second is the focus of this paper.

\section{Hypotheses}

The paper seeks to disentangle a variety of simultaneous causal relationships, on a cross-country data set. The question of central interest is the effect of international trade

\footnotetext{
${ }^{1}$ The quotation marks are necessary around "non-economic," because economists' conceptual framework fully incorporates such objectives as environmental quality, even though pollution is an externality that is not measured by GDP. Frankel (2002) reviews recent controversies surrounding globalization and the environment.
} 
on the environment, for a given level of GDP. We consider certain causal relationships as already fairly well established:

1) Openness has a positive effect on countries' real income per capita. Economists have long made the theoretical case, from the Smith-Ricardo idea of comparative advantage to the Helpman-Krugman model of trade under imperfect competition. The empirical case is also moderately strong.

2) Output has a positive effect on pollution through the physical scale of production, but at the same time,

3) At higher levels of income per capita, growth raises the public's demand for environmental quality, which, given the right institutions, can translate into environmental regulation. People value both their economic standard of living as measured by GDP and the environment as well. Environmental regulation, if effective, then translates into a cleaner environment. The ratio of pollution to GDP can be improved through a composition channel and a technique channel. While the effects described under propositions (2) and (3) go opposite directions, there is by now a rough conventional wisdom that the negative effect of growth on environmental quality dominates at low levels of income, while the positive effect may dominate at higher levels. This proposition is: 
4) The environmental Kuznets curve: the relationship between income per capita and some kinds of pollution is roughly shaped as an inverted $\mathrm{U}$. The World Bank (1992) and Grossman and Krueger $(1993,1995)$ brought to public attention this empirical finding. ${ }^{2}$ Growth is bad for air and water pollution at the initial stages of industrialization, but later on reduces pollution, as countries become rich enough to pay to clean up their environments. The standard theoretical rationale is that production technology makes some pollution inevitable, but that demand for environmental quality rises with income. $^{3}$

${ }^{2}$ Grossman and Kruger $(1993$, 1995) found the Kuznets curve pattern for urban air pollution (SO2 and smoke) and several measures of water pollution. Selden and Song (1994) found the pattern for SO2, suspended particulate matter (PM), NOx, and carbon monoxide. Shafik (1994) found evidence of the U shape for deforestation, suspended $\mathrm{PM}$, and SO2, but less for water pollution and some other measures. Among more recent studies, Hilton and Levinson (1998) find the U-shaped relationship for automotive lead emissions and Bradford, Schlieckert and Shore (2000) find some evidence of the environmental Kuznets curve for arsenic, COD, dissolved oxygen, lead and SO2, while finding less evidence in the cases of PM and some other measures of pollution. Bimonte (2001) finds the relationship for the percentage of land that is protected area, within national territory. Harbaugh, Levinson, and Wilson (2000) point out that the relationship is very sensitive with respect, for example, to functional form and updating of the data set.

${ }^{3}$ Theoretical derivations include Andreoni and Levinson (1998), Jaeger and Kolpin (2000), Selden and Song (1995) and Stokey (1998), among others. Another explanation is that the compositional pattern results from the stages of economic development, the transition from an agrarian economy to manufacturing to services (Arrow, et al, 1995; Panayotou, 1993). This explanation is not inconsistent with the usual view, but it is less likely to require the mechanism of effective government regulation. In terms of our testable implications, if the Kuznets curve results solely from this composition effect, then high incomes should lead to a better environment even in the absence of democracy at the national level and even when externalities arise at the international level. 
To portray the Kuznets curve as claiming that if countries promote growth, the environment will eventually take care of itself, would be an unfair caricature. This optimistic view applies to pollution only if it is largely confined within the home or within the firm. ${ }^{4}$ Most pollution, such as $\mathrm{SO} 2$, NOx, etc., is external to the home or firm. For such externalities, higher income and a popular desire to clean up the environment are not enough. There must also be effective government regulation, which usually requires a democratic system to translate the popular will into action (something that was missing in the Soviet Union, for example), as well as the rule of law and reasonably intelligent mechanisms of regulation. That is at the national level; the requirements for dealing with cross-border externalities are greater still.

We will be testing the environmental Kuznets curve, along with the other propositions on this list. But it is not the central focus of the paper.

The central focus of the paper is, rather:

5) The effect of trade on the environment for a given level of income per capita.

This is an interesting question for two reasons. First, it is perhaps the most relevant fundamental question for policy. If it were established that trade had an adverse effect on the environment solely because openness raised countries' incomes, and the higher incomes damaged the environment, in practice few would conclude from this that

\footnotetext{
${ }^{4}$ Perhaps 80 percent (by population) of world exposure to particulates comes from cooking fire smoke in poor countries, which need not involve any externality. Chaudhuri and Pfaff (2002) find a U-shaped relationship between income and indoor smoke, across households. In the poorest households, rising incomes mean more cooking and more indoor pollution. Still-higher incomes allow a switch to cleaner fuels. Engel curves can produce the relationship, with no role for government regulation.
} 
we should try to turn back the clock on globalization. Few would choose deliberate selfimpoverishment as a means to a clean environment. ${ }^{5}$

Secondly, the question is interesting because the answer is completely unknown. There are possible effects in both directions. Most widely discussed is the race to the bottom hypothesis, which says that countries that are open to international trade (and investment) will adopt looser standards of environmental regulation, out of fear of a loss in international competitiveness. ${ }^{6}$

Less widely recognized is the possibility of an effect in the opposite direction, which we will call the gains from trade hypothesis. Trade allows countries to attain more of what they want, which includes environmental goods in addition to marketmeasured output. How could openness have a positive effect on environmental quality, even for a given level of GDP per capita? One widely identified possibility is an international ratcheting up of environmental standards. ${ }^{7}$ A second possibility concerns

\footnotetext{
${ }^{5}$ Meadows, et al (1972), and Daly (1993), could, however, be interpreted as arguing that trade is necessarily bad because it raises measured GDP which in turn harms the environment. For a general survey of the issues, see Esty (2001).

${ }^{6}$ What is competitiveness? Economists tend to argue that concerns regarding international competitiveness, if interpreted as fears of trade deficits, are misplaced, which would seem to imply they would not affect rational policy-making. Or else, to the extent competitiveness concerns can be interpreted as downward pressure on regulation commensurate with cost considerations, economists figure that they may be appropriate. But Esty and Gerardin (1998, p. 17-21) point out that competitiveness fears, under actual political economy conditions, may have a greater effect on environmental standards than is rational, particularly by creating a political drag against new regulation.

${ }^{7}$ E.g., Vogel (1995), Porter (1995), and Braithwaite and Drahos (2000). This ratcheting up may be more effective for product standards than for standards regarding production processes and methods.
} 
technological and managerial innovation. ${ }^{8}$ Multi-national corporations tend to bring clean state-of-the-art production techniques from high-standard countries of origin, to host countries where they are not yet known, for several reasons:

"First, many companies find that the efficiency of having a single set of management practices, pollution control technologies, and training programmes geared to a common set of standards outweighs any cost advantage that might be obtained by scaling back on environmental investments at overseas facilities. Second, multinational enterprises often operate on a large scale, and recognise that their visibility makes them especially attractive targets for local enforcement officials...Third, the prospect of liability for failing to meet standards often motivates better environmental performance..." -- Esty and Gentry (1997, p.161)

Trade economists think that openness encourages ongoing innovation, that this may be why countries that trade more appear to experience a sustained increase in growth rather than just the one-time increase in the level of real income predicted by classical trade theory. Trade speeds the absorption of frontier technologies and best-practice management. It then seems likely that openness could encourage innovation that would be beneficial to environmental improvement as well as economic progress.

Another possibility is that, because trade offers consumers the opportunity to consume goods of greater variety, it allows countries to attain higher levels of welfare (for any given level of domestically produced output), which, as under proposition (3) above, will raise the demand for environmental quality. Again, if the appropriate

\footnotetext{
${ }^{8}$ Esty and Gentry (1997, pp. 157, 161, 163) and Schmidheiny (1992). Eskeland and Harrison (2002) find that, within given sectors in given developing countries, foreign plants are significantly more energy efficient and use cleaner types of energy than domestic plants.
} 
institutions are in place, this demand for higher environmental quality will translate into effective regulation and the desired reduction in pollution. ${ }^{9}$

Whether the race-to-the-bottom effect dominates the gains-from-trade effect is an empirical question.

Figure 1 is a schematic illustration of the causal relationships that are hypothesized above, and several others as well. Two controversial propositions are:

6) The pollution haven hypothesis: To the extent that countries are open to trade and investment, some (e.g., those with low demand for environmental quality) will adopt lax environmental standards to attract multinational corporations and export pollution-intensive goods, while others (e.g., those with high demand for environmental quality) will adopt high standards and import pollution-intensive goods. It is worth emphasizing one of the differences between the race-to-the-bottom hypothesis and the pollution haven hypothesis: while the former implies an overall world level of environmental regulation that is less than optimal, the latter does not. Some countries may

\footnotetext{
${ }^{9}$ A final possibility is that globalization offers interest groups that care particularly about the environment new weapons. Domestically, they can threaten to block the trend toward free trade unless they are bought off. [This is by analogy with the "embedded liberalism" identified by Ruggie (1982), a post-war quid pro quo that gave workers an increased level of social protection, in exchange for an open international trading regime.] Across borders, the new weapons include consumer labeling for imports and corporate codes of conduct for multinationals.
} 
choose high environmental standards for their own production, and import from others goods that embody pollution. ${ }^{10}$

7) The Porter hypothesis: a tightening of environmental regulation stimulates technological innovation and thereby has positive effects on both the economy and the environment -- for example, saving money by saving energy. ${ }^{11}$ The analytical rationale for this view is not entirely clear. (Is the claim that any sort of change in regulation, regardless in what direction, stimulates innovation, or is there something special about pro-environment regulation? Is there something special about the energy sector?) Nevertheless the Porter hypothesis is sufficiently widely discussed that it merits a position on our list of propositions to be taken into account.

${ }^{10}$ Some economists' research suggests that environmental regulation is not a major determinant of firms' ability to compete internationally. When deciding where to locate, multinational firms seem to pay far more attention to such issues as labor costs and market access than to the stringency of local environmental regulation: Jaffe, Peterson, Portney and Stavins (1995), Low and Yeats (1992), and Tobey (1990). Other empirical researchers, however, have found more of an effect of environmental regulation: Lee and Roland-Holst (1997) and Smarzynska and Wei (2001). Theoretical analyses include Copeland and Taylor $(1994,1995,2001)$ and Liddle (2001).

${ }^{11}$ Porter and van der Linde (1995). 


\section{THE RELATIONSHIP BETWEEN TRADE AND ENVIRONMENT Hypothesized causal relationships}

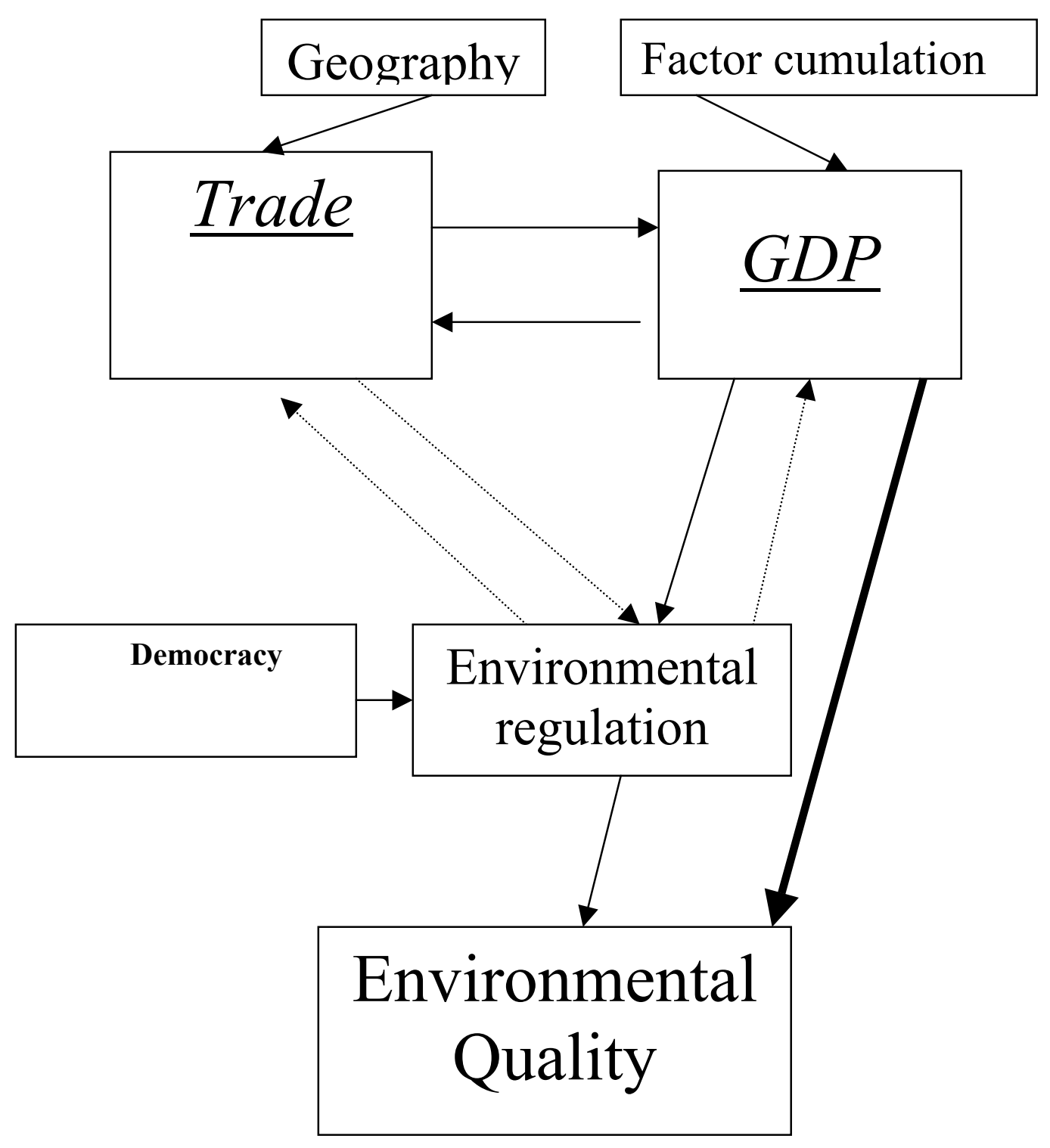

1. Economic gains from trade

3. Environmental Kuznets curve whether negative (usual) or positive (Porter Hypothesis)

5. Effect of trade on environment, whether adverse (race to the bottom) or positive (environmental gains from trade)
2. Reverse causality from income to trade

4. Effect of regulation on productivity,
6. Pollution haven hypothesis 


\section{Endogeneity}

This list of propositions includes important possible causal arrows running in both directions among each pair out of the three key endogneous variables - trade, income, and the environment. In estimating a system of equations, the simultaneity problems are formidable. Let us say that we find a positive correlation between trade and environmental quality. Eiras and Schaeffer (2001, p. 4), for example, find: "In countries with an open economy, the average environmental sustainability score is more than 30 percent higher than the scores of countries with moderately open economies, and almost twice as high as those of countries with closed economies." Does this mean that trade is good for the environment? Not necessarily. It might be a result of the Porter hypothesis -- environmental regulation stimulates productivity -- together with the positive effect of income on trade. Or it might be because democracy leads to higher levels of environmental regulation, and democracy is causally intertwined with income and trade.

A couple of studies seek to isolate the independent effect of openness. Harbaugh, Levinson, and Wilson (2000, Table 4) report (in passing) a beneficial effect of trade on the environment, controlling for income. Antweiler, Copeland and Taylor (2001), which is probably the most careful existing study explicitly focused on the effects of trade on the environment, estimates an effect that is favorable (though only of borderline significance, statistically speaking). But neither study makes allowance for the problem that trade may be the result of other factors rather than the cause.

Or let us say that we were to find a negative correlation between trade and environmental quality. Does this mean that trade is bad for the environment? Not 
necessarily. It might be a result of a negative effect of environmental regulation on growth, together with the positive effect of growth on trade. ${ }^{12}$

The endogeneity of trade is a familiar problem in the empirical literature on whether openness promotes growth. Rodrik (1995), for example, argues that the common finding of a positive correlation between trade and per capita income is "quite misleading on the importance it attaches to the role of export-orientation in the growth performance. It also has backward the causal relationship between exports, on the one hand, and investment and growth on the other." Similarly, Helpman $(1988$, p.6) asks "Does growth drive trade, or is there a reverse link from trade to growth?" Harrison (1995) concludes that "existing literature is still unresolved on the issue of causality."

Quite a few stories of reverse causality, running from income to trade, are possible. The mechanism that Rodrik, or Levine and Renelt (1992), have in mind runs as follows: an exogenous increase in investment in a developing country with a comparative disadvantage in producing capital goods will necessitate an increase in imports of such goods. Another mechanism is that trade might rise with income because foreign goods are superior goods in consumption. Many studies have sought to identify some direct measures of trade policy, hoping that they are exogenous. But, aside from difficulties in measuring trade policies, which are typically serious enough, a fundamental conceptual problem of simultaneity remains (e.g., Sala-i-Martin, 1991). What if free-market trade policies are no more important to growth than free-market domestic policies, but tend to be correlated with them?

\footnotetext{
${ }^{12}$ The same ambiguity attaches to correlations among the other pairs of variables. For example, Esty and Porter (2001) find a positive correlation between income and environmental regulation. Their preferred interpretation is the Porter hypothesis, but they are obligate to admit that "These findings do not establish causality." (p. 26).
} 
Then openness will be observed to be correlated with growth, even though trade does not cause growth. A final possible mechanism is a pattern whereby poor countries tend to depend fiscally on tariff revenue, and to reduce tariffs as they become more developed.

What is needed is a good instrumental variable, which is exogenous yet highly correlated with trade. The gravity model of bilateral trade offers a solution. This model says that trade is determined by indicators of country size (GDP, population, and land area) and of distance between the pair of countries in question (physical distance as well as dummy variables indicating common borders, linguistic links, and landlocked status). ${ }^{13}$ Such geographical variables are plausibly exogenous. Yet when aggregated across all bilateral trading partners these variables are highly correlated with a country's overall trade, and thus make good instrumental variables. Such gravity instruments have recently been used to isolate the effect of trade in studies of growth (Frankel and Romer, 1999; Irwin and Tervio, 2001), studies of currency union (Frankel and Rose, 1996, 2002), and studies of inequality (Chakrabarti, 2000, and Gurkaynak and Krashinsky, 2001).

Income too is endogenous. We thus also use a second set of instrumental variables, for income per capita, from the growth literature: lagged income (the conditional convergence hypothesis), size (Frankel and Romer, 1999; Frankel and Rose, 2002), and rates of investment rates and human capital formation (the factor accumulation variables familiar from neoclassical growth equations: Solow, 1956; Barro, 1991; Mankiw, Romer and Weil, 1992).

As always, there is the possibility that some of our instrumental variables are in truth endogenous. This could be an issue with the factor accumulation variables in the

${ }^{13}$ Frankel (1997) offers a comprehensive review of the gravity model. 
income equation: Concern has been expressed that investment is endogenous, or that human capital is. ${ }^{14}$ To us, the geographic variables seem the least likely to be endogenous, not just in a causal sense, but also in the econometric sense, i.e., correlated with the error term in the trade equation. These are the instruments we need for testing our question of central interest, the effects of trade on the environment for a given level of income.

\section{Results}

We estimate a system of two equations:

Growth equation:

$$
\begin{aligned}
& \ln (\mathrm{Y} / \mathrm{Pop})_{90, \mathrm{i}}=\beta_{0}+\alpha([\mathrm{X}+\mathrm{M}] / \mathrm{Y})_{90, \mathrm{i}}+\beta_{1} \ln (\mathrm{Pop})_{\mathrm{i}}+\phi \mathrm{Z}_{\mathrm{i}} \\
& +\not \ln (\mathrm{Y} / \mathrm{Pop})_{70, \mathrm{i}}+\delta_{1}(\mathrm{I} / \mathrm{Y})_{\mathrm{i}}+\delta_{2} \mathrm{n}_{\mathrm{i}}+\delta_{3}(\mathrm{School} 1)_{\mathrm{i}}+\delta_{4}(\mathrm{School} 2)_{\mathrm{i}}+\mathrm{u}_{\mathrm{i}}
\end{aligned}
$$

The dependent variable is the natural logarithm of GDP (Y) divided by total population (Pop) at the end of 1990, measured in real PPP-adjusted dollars for country $i$. Aggregate exports, aggregate imports, and gross investment are denoted "X", "M" and "I" respectively. The growth rate of population is denoted "n". "School," and "School 2 " are estimates of human capital investment based, respectively, on primary and secondary schooling enrollment rates. "Z" denotes other controls; Greek letters denote coefficients; and "u" denotes the residual impact of other, hopefully orthogonal influences. We denote by "controls" the variables that derive from neoclassical growth theory and appear on the

${ }^{14}$ E.g., Bils and Klenow (1998) argue that investment in human capital is endogenous with respect to growth. It is also possible that the political variables are endogenous, with richer countries tending to become more democratic. 
second line of the equation: initial income, investment, human capital and population growth. ${ }^{15}$ Variables other than GDP per capita and openness are computed as averages over the sample period. Following the norm in the growth literature, we measure openness as the ratio of trade to output.

\section{Environmental quality equation:}

$$
\begin{aligned}
& \text { EnviroDamage }_{i}=\varphi_{0}+\varphi_{1}\left(Y / \text { pop }_{1}\right)_{90, i}+\varphi_{2}\left(Y / \text { pop }_{2}\right)_{90, i}{ }^{2} \\
& +\mu([X+M] / Y)_{90, i}+\pi\left(\text { Polity }_{90, i}+\lambda(\text { LandArea } / \text { Cap })_{90, i}+e_{i} .\right.
\end{aligned}
$$

The dependent variable is any of three of measures of pollution or other measures of environmental damage, each estimated as separate equations. The first two variables are per capita income and per capita income squared, for country $i$. The EKC hypothesis predicts that the coefficient on the latter is negative, so that the pollution curve eventually turns down. As an alternative to the quadratic functional form, we also tried the three segments of a spline (split at the .33 and .66 percentiles) fit to the natural logarithm of per capita income. Per capita income is again defined as real 1990 GDP (Y) divided by total population (Pop), taken from the Penn World Table 5.6, which is measured in real PPPadjusted dollars. Aggregate exports and aggregate imports as before are denoted " $X$ " and

\footnotetext{
${ }^{15}$ Frankel and Romer (1999) and Irwin and Tervio (2000) adopt a more stripped-down specification by omitting these controls, following Hall and Jones (1999). They regress output per capita against distance from the equator and measures of country size, reasoning that the factor accumulation variables might be endogenous. Including the controls in the output equation might result in a downward-biased estimate of $\alpha$, if some of the effect of openness arrives via factor accumulation. But inappropriately excluding these variables would also produce biased results and could be expected improperly to attribute too large an effect to trade. Our own preference is for the specification that includes the controls, in part because it is likely to avoid a possible upward bias in the openness coefficient.
} 
" $M$ "; Polity is a measure of how democratic is the structure of the government, ranging from -10 ("strongly autocratic") to +10 (strongly democratic). ${ }^{16}$ Land area per capita is intended to allow for the likelihood that population density leads to environmental degradation (for a given level of per capita income) ${ }^{17} \quad$ Again, allowing for the endogeneity of trade and income is the main new contribution of this paper.

We focus on results for three measures of air pollution:

$\mathrm{SO}_{2}$ : sulphur dioxide, mean (in micograms per cubic meter), 1995

$\mathrm{NO}_{2}$ : nitrogen dioxide, mean (in micograms per cubic meter), 1995

PM: Suspended Particulate Matter, mean total (in micograms per cubic meter), 1995

We have also looked at four other measures of environmental quality:

$\mathrm{CO}_{2} /$ cap: Carbon dioxide emissions, industrial, in metric tons per capita

Def: annual deforestation, average percentage change, 1990-95

Energy: Energy depletion, in percent of GDP ("genuine savings") ${ }^{18}$, and

Water: Access to clean water (percentage of rural population) 1990-1996.

Of these seven, the three measures of local air pollution -- $\mathrm{SO}_{2}, \mathrm{NO}_{2}$, and $\mathrm{PM}$-- are the most relevant. As noted, $\mathrm{CO}_{2}$ is a purely global externality, and unlikely to be addressed

${ }^{16}$ It is taken from the Polity IV Project at the University of Maryland., described in Marshall and Jaggers (2000). Barrett and Graddy (2000) also find that an increase in civil and political freedoms significantly reduces some measures of pollution.

${ }^{17}$ Cropper and Griffiths (1994) study deforestation and find that, in addition to the usual Kuznets curve effect of per capita income, population density has a further adverse effect.

${ }^{18}$ Energy depletion is a measure computed for the World Bank's World Development Indicators. It is equal to the product of unit resource rents and the physical quantities of fossil fuel energy extracted (including coal, crude oil, and natural gas). Table 3.15, available at http://www.worldbank.org/data/wdi2001/pdfs/tab3 15.pdf, explains the data computations. 
by regulation at the national level. Deforestation ${ }^{19}$ and Energy depletion are not measures of pollution, and measuring them involves some serious problems of composition and data reliability, as does water access. But we thought that it was worth at least taking a look at these broader measures of environmental quality.

\subsection{Results for the Growth Equation}

We begin by estimating our output equation, equation (1), to replicate the common finding that there is a statistical association between trade and income. In Table I, we report OLS estimates of the impact of trade on output. The coefficient on initial GDP is a highly significant 0.71 , representing a plausible degree of conditional convergence -- about 30 percent over a 20 -year period. The estimated coefficient on trade, 0.33 in the OLS version, says that, holding constant for 1970 income, income in 1990 was $1 / 3$ per cent higher for every 1.0 percentage point increase in the trade/GDP ratio. When multiplied by $3.45(=1 /(1-.71))$ to convert to an estimated effect on long-run income, the effect on output is 1.14 per cent for every 1.0 percentage point increase in openness.

The effects of investment and both schooling variables are statistically significant and reasonable. Population growth has the negative sign hypothesized by the neoclassical model, but as in earlier work is the one growth determinant that is not statistically significant.

\footnotetext{
${ }^{19}$ It seems plausible that trade in wood products might lead to some chopping down of trees. For example, Brooks, et al. (2001), estimate that the Accelerated Tariff Liberalization initiative now underway in forest products may increase aggregate world trade in this sector by 2 percent and increase the world timber harvest by 0.5 per cent. But, as they note, this need not imply net deforestation, since planting increases as well.
} 


\section{[Table 1 about here.]}

The next step is to estimate the corresponding output equation using IV estimation to account for the possible endogeneity of openness. The instrumental variables we choose come from a simple gravity model that uses as controls an aggregation of: the log of distance, the log of partner country population, the log of area, and dummy variables for common language, common land border, and landlocked status. After estimating the gravity model for a large data set on pairwise trade, we aggregate the exponent of the fitted values across bilateral trading partners to arrive at a prediction of total trade for a given country. The correlation between actual trade shares and our generated instrument is a reassuringly high value of $.72 .^{20}$ Table I also reports the IV estimate of equation (1). The estimate of interest to us here is $\alpha$, the coefficient on openness. When we include initial income and other controls, the effect of trade on output is 0.43 . The implied steady state impact is $1.6(=.43 /(1-.73))$.

The Porter Hypothesis reverses conventional economics wisdom by suggesting that aggressive efforts to protect the environment can be good for productivity growth. A crude way to test this hypothesis is to include measures of environmental quality on the right-hand side of the growth equation, using the polity variable as an instrument to

\footnotetext{
${ }^{20}$ See Frankel and Rose (2002) for results of the estimation of the bilateral trade equation and details of the calculation of the gravity instrument, which corresponds closely to that used here. That paper also includes a response to critiques from Rodriguez and Rodrik (2001) and Rodrik (2000) regarding the gravity instruments. The most difficult part of the controversy concerns whether trade can be assumed to have similar effects on growth when the "globalization" arises from deliberate policy (such as trade liberalization) as when it arises from geographic and technological factors (such as proximity or declining shipping costs).
} 
control for the endogeneity of environmental quality. When we tried this, we found no support for the hypothesis of a positive effect on growth. [Results not reported here].

\subsection{Results for Pollution: Race to the Bottom, or Gains from Trade?}

Table 2 reports the results of OLS estimation of equation (2), where the dependent variable is represented by the three measures of air pollution. The estimated effect of the polity variable on pollution is always negative, suggesting that improved governance has a beneficial effect. It is generally significant statistically. The same is true of land area per capita, offering some evidence that population density has an adverse effect on pollution.

Of greater interest is the relationship with per capita income. The estimated coefficient on the quadratic term is negative for all three measures of air pollution, confirming the EKC hypothesis: after a certain point, growth is good for the environment. Statistically, it is highly significant in the case of $\mathrm{SO} 2$ and $\mathrm{NO} 2$, and moderately significant in the case of PM.

When we used a spline function in place of a quadratic, the results again tend to support the EKC [Table A2]. That is, increases in income in the low-income countries increases pollution, and in the high-income countries reduces it. The adverse effect in the low-income range is insignificant for $\mathrm{SO}$, but is highly significant for suspended particulate matter. The effect in the high-income range is significant for PM, borderline significant for $\mathrm{SO}$, and insignificant for $\mathrm{NO}$. The measure that does not exhibit a clear Kuznets curve in the spline case is NO2, where the adverse effect does not show up until the middle third of the spline. 
The quadratic specification is far more common than the spline in the literature, and is probably better. It is less arbitrary in its cut-off points and yet more sparing in degrees of freedom. Also it allows one to try to identify the level of income at which pollution peaks. The OLS point estimates say that PM peaks at an income level of $\$ 2,882$ per capita, $\mathrm{SO} 2$ at $\$ 5770$ per capita, and $\mathrm{NO} 2$ at $\$ 7665$ per capita.

\section{[Table 2 about here.]}

Our central interest is in $\mu$, the coefficient on openness. The coefficient on openness is negative for all three kinds of air pollution - insignificantly so for PM, moderately significant for NO2, and highly significant for SO2. Apparently any adverse "race to the bottom" effect on air pollution is outweighed by positive "gains from trade"

effects. When we use the spline for income, the same results emerge for openness [Table A2].

The contribution of this paper is to address the possibility that these apparent effects may be the spurious results of simultaneity. Table 3 estimates the environmental equation via instrumental variables, where the gravity-derived prediction of openness is the instrument for trade and the factor accumulation variables are the instruments for income.

\section{[Table 3 about here.]}

The IV results are generally similar to the OLS results, though with somewhat diminished significance levels in some cases. The EKC is still there for all three pollutants: $\mathrm{SO} 2, \mathrm{NO} 2$, and $\mathrm{PM}$. In the IV results of Table 3, the coefficient on openness is negative for all three pollution measures. As in the OLS results, statistical significance is high for $\mathrm{SO}$, moderate for $\mathrm{NO}$, and altogether lacking for PM. (When 
the income relationship is estimated with a spline instead of a quadratic form, in Table A3, the effect on pollution again turns down for all three measures. The general pattern of coefficients on openness is the same as in the OLS estimates.)

\subsection{Results for Other Environmental Measures}

Air pollution is only one kind of measure of environmental quality. We also tried these tests with some others: carbon dioxide, deforestation, energy depletion, and access to clean water. As noted, the measurement difficulties tend to be much greater than with air pollution. The OLS results are reported in Tables 4 (for the case of quadratic EKC) and (for the spline). In most cases, the effects of polity, area, and quadratic income go in the same direction as with the air pollution indicators. The Kuznets curve shows up with high statistical significance for deforestation, energy depletion, and rural water access. Beneficial effects of openness show up only for energy depletion and water access, and are of borderline statistical significance. (In the case of water access, a positive coefficient indicates a beneficial environmental effect, the reverse of the other six indicators.)

\section{[Tables 4 and 5 about here]}

The case that would give an environmentalist the greatest concern is $\mathrm{CO} 2$. The coefficient on quadratic income is positive and highly significant. In the spline version as well, growth continues to have a positive, indeed increasing, effect through all three segments in the case of $\mathrm{CO} 2$. This confirms findings of other researchers, as well as a priori reasoning: $\mathrm{CO} 2$ is a purely global externality, so that there is no reason to expect individual countries to address it on their own, no matter what their level of income. 
Furthermore, the coefficient on openness is apparently positive, and of moderate significance in the OLS case. This result could be viewed as one piece of evidence supporting the idea that global warming cannot be addressed without an international treaty, or at least has not been. ${ }^{21}$

The IV results are reported in Tables 5 (for the case of quadratic EKC) and A4 (for the spline). While some results, such as the Kuznets curve, differ very little from OLS, in some other cases the use of instrumental variables makes a difference. Encouragingly, the apparently detrimental effect of openness on carbon dioxide emissions loses all significance, awhile the apparently beneficial effect on energy depletion becomes significant (at the 10\% level). On the other hand, the beneficial effect on water access (which was not quite significant under OLS) disappears.

Thus the results continue to be generally supportive of both the Kuznets curve and the proposition that openness is at least as likely to help the environment, for a given level of income, as to hurt it. The only case where growth appears always detrimental for the environment -- and openness perhaps to exacerbate the problem, though significance disappears under IV -- is $\mathrm{CO} 2$. This is the one gas on our list that is a purely global externality, where countries cannot expect to be able to address it by national regulation on their own, and indeed where fears of adverse effects on competitiveness are most acute.

${ }^{21}$ Of course, we cannot rule out that emissions of $\mathrm{CO} 2$ also follow a Kuznets Curve, but that the peak is not reached until higher levels of income than yet experienced by rich countries. (Schmalensee, Stoker and Judson, 1996.) But, as Dua and Esty (1997, p. 74) point out, that the ability to control pollution would diminish with the geographical diffusion of the externality is exactly what one would expect. 


\subsection{Do Some Countries Have a "Comparative Advantage" in Pollution?}

To summarize the results regarding openness so far, trade, if anything, appears

often to have a beneficial effect on measures of environmental quality, for given levels of income. The cases where the effect is statistically significant, particularly $\mathrm{SO} 2$ and $\mathrm{NO}$, are cases where the effect is beneficial. We interpret the absence of a general upward effect of openness on environment degradation as evidence against the "race to the bottom" hypothesis. ${ }^{22}$

Putting aside now the effects on the overall level of environmental quality worldwide, one might also be concerned about a possible "pollution haven" hypothesis according to which economic integration results in some countries exporting pollution to others, even if the overall level of pollution does not rise. One version of the hypothesis would be that countries that have a particularly high demand for environmental quality e.g., the rich countries -- specialize in products that can be produced cleanly, and they let the poor countries produce and sell the products that require pollution. ${ }^{23}$ This hypothesis can be readily tested by adding to the environment equation the product of openness and

${ }^{22}$ Good economic practice forbids interpreting the absence of statistically significant rejections of the null hypothesis as proof that the null hypothesis is true. The test can have low power. Still, this is not one of those contexts where one would necessarily expect low power on a priori grounds (as one would, for example, when testing the hypothesis that a financial spot price follows a random walk -- Frankel, 1990). Many observers claim to see in the world around them evidence that trade is bad for the environment. Thus our inability to find it in when looking across countries has some meaning.

${ }^{23}$ E.g., Suri and Chapman (1998) find that middle-income countries' growth only leads to lower domestic pollution if they increase imports of manufactures. Muradian, O'Connor and Martinez-Alier (2001) have found recent evidence that the imports of rich countries embody more air pollution than their exports. Levinson and Taylor (2001) find that those US industries experiencing the largest rise in environmental control costs have also experienced the largest increases in net imports. 
income per capita. If rich countries take advantage of trade by exporting pollutioncreating activities to poor countries, the interaction between openness and income should have a negative effect on the level of a country's domestic pollution. When we tried this as an extension, we found that the estimated coefficient on the interactive term in most cases not significant. The exceptions are PM and to some extent SO2; under either OLS or IV estimation, openness interacted with income appears to have a positive effect on these types of pollution. But this is the opposite of the sign predicted by the pollution haven hypothesis, which says that it is poor countries for whom trade leads to exploitation of the environment, with rich countries supposedly specializing in clean products.

\section{[Table 6 about here]}

A second version of the pollution haven hypothesis would be that countries that are endowed with a particularly high supply of environmental quality - e.g., those with high land area per capita become pollution havens and import clean goods from those that are more densely populated. We tested this by adding the product of openness and land area per capita. Again, signs were divided between negative and positive, and coefficients were usually not at all significant. The only two cases where the coefficient on the interactive term was moderately significant -- IV for PM and OLS for CO2 -again showed the wrong sign, counterintuitively suggesting that to the extent countries are open to trade, those that are sparsely populated have lower emissions than they otherwise would, not higher. In any case, there is no evidence for the pollution haven effect.

[Table 7 about here.] 
A third possible source of "comparative advantage" derives from traditional trade theory. If some countries have a comparative advantage in capital intensive sectors such as mining or heavy manufacturing and other countries in labor intensive sectors, and if the former sectors are more polluting than the latter, then trade may lead to an increase in pollution among the capital-endowed countries and a decrease among the labor-endowed countries. Note that this version of the comparative advantage hypothesis is likely to imply that trade leads to lower pollution in poor countries, the opposite of the prediction of the first version considered above. (Rich countries usually have higher capital/labor ratios than poor countries, though not always.) We tested this version by including interactive terms defined as openness times the country's capital/labor ratio. The signs were negative as often as positive. Standard errors were large. In only one case out of 14 did the interactive term appear statistically significant: in the OLS estimate for $\mathrm{CO} 2$, the coefficient was positive and significant. This one case would suggest that international trade encourages capital-intensive countries to emit more carbon, and laborintensive countries to emit less. The finding vanishes under IV estimation.

\section{[Table 8 about here.]}

To summarize this section, there is no evidence of that some countries use trade to exploit a comparative advantage in exporting pollution and others in importing it. This applies equally to versions that hypothesize countries deliberately setting pollution regulation so as to respond to their environmental comparative advantage, and to the version that says capital intensive countries will naturally pollute more as a side effect of trading according to comparative advantage. The only cases where the coefficient on the interactive term appears significant are of the wrong sign. 


\section{Conclusions}

Trade can have several sorts of effects on the environment. We have found evidence that, for any given level of income, trade appears to have a beneficial effect on some measures of environmental quality, though not all. This is particularly true of measures of air pollution, such as SO2. Even among other measures of environmental quality, one can at least say that there is no evidence that trade has the detrimental overall effect on the environment that the race-to-the-bottom theory would lead one to expect. There is also no evidence for the pollution haven hypothesis, which claims that to the extent countries engage in trade, some will specialize in dirtier environments and others in clean. In addition, trade helps promote economic growth, which in turn is an indirect channel of effect on the environment. At low levels of income this effect is detrimental to the environment, at high levels beneficial.

\subsection{A Sample Calculation}

An interesting question is whether, within the class of low-income countries, the direct beneficial effect of openness is large enough to offset the indirect effect via income. The openness coefficient is too variable across measures of pollution and is estimated too imprecisely to allow us to answer this question reliably. But an illustrative calculation may still be instructive. The environmentally damaging phase of the Kuznets curve is particularly strong for energy depletion, so let us take this case. Table 1 reports that for every 1 percentage point increase in openness, income rises by an estimated 0.3 
percentage points (over the subsequent 20 years). The relevant coefficient from Table A2 implies that, in a poor country, this economic growth in turn induces energy depletion of $8.5 * 0.3=2.6$. At the same time, the 1 percentage point increase in openness diminishes energy depletion by an estimated 3.3 for a given level of income. Taking the difference of the two effects produces an estimated beneficial net effect.

We must be sure not to read much into this calculation of the net effect. The difference is not statistically significant. Furthermore, the estimated net effect is much better than this for some of the measures of environmental damage, and much worse for others. But if it is necessary to attempt an overall verdict, it is also worth recalling two key points. Even if the two effects of trade on pollution cancelled out, that would still leave the country with a higher level of income and no change in environmental quality. Furthermore, once the country gets past the peak in the Kuznets curve, the two effects of openness, indirectly via income and directly, go the same direction.

\subsection{Summary of Conclusions}

The results regarding the effects of trade and growth on air pollution, measured here by SO2, NO2 and Particulate Matter, are generally good. We confirmed the pattern of the environmental Kuznets curve, whereby growth eventually has a beneficial effect on pollution, after the initial adverse relationship at low levels of income. Trade accelerates the growth process. However the primary emphasis of the paper was on the effect of openness for a given level of income. Here we found little or no evidence of the race to the bottom hypothesis. To the contrary, a higher ratio of trade to income, for a given level of income, seems if anything to reduce air pollution. The new contribution 
of the paper is to address the likely endogeneity of trade, by means of instrumental variables drawn from the gravity model. The relationship holds up, suggesting that the observed correlation between trade and environmental quality is not attributable to other factors.

The results are more mixed when one tries broader measures of environmental quality. In particular, the optimistic story does not hold for the case of CO2. Here there is no evidence that the Kuznets curve ever turns down on its own. Furthermore, openness is estimated under OLS to have a detrimental effect even for a given level of income, although, encouragingly, the latter effect disappears under IV estimation. In this case, trade and growth alone won't do it. International cooperation is also needed to address this sort of global environmental problem. 


\section{$\underline{\text { References }}$}

Andreoni, James, and Arik Levinson 1998, "The Simple Analytics of the Environmental Kuznets Curve," NBER Working Paper no. 6739, September.

Antweiler, Werner, Brian Copeland and M. Scott Taylor, 2001, "Is Free Trade Good for the Environment?” NBER Working Paper No. 6707. American Economic Review, 91, no. 4, September, 877-908.

Arrow, K., R. Bolin, P. Costanza, P. Dasgupta, C. Folke, C.S.Holling, B.O. Jansson, S.Levin, K.G. Maler, C.Perrings, and D.Pimentel, 1995, "Economic Growth, Carrying Capacity, and the Environment," Science 268, 520-521, April 28.

Barrett, Scott, and Kathryn Graddy, 2000, "Freedom, Growth, and the Environment," Environment and Development Economics 5, 433-456.

Barro, Robert, "Economic Growth in a Cross Section of Countries," Quarterly Journal of Economics, CVI (May 1991), 407-444.

Bils, Mark, and Peter Klenow, 1998, "Does Schooling Cause Growth or the Other Way Around?" NBER Working Paper no. 6393, Feb.

Bimonte, Salvatore, 2001, "Model of Growth and Environmental Quality: A New Evidence of the Environmental Kuznets Curve," Department of Economics, Universita di Siena, April; available from the SSRN Electronic Paper Collection:

http://papers.ssrn.com/paper.taf?abstract_id $=286740$

Bradford, David, Rebecca Schlieckert and Stephen Shore, 2000, “The Environmental Kuznets Curve: Exploring a Fresh Specification,” NBER Working Paper no. 8001.

Braithwaite, John, and Peter Drahos, Global Business Regulation, Cambridge University Press, UK.

Brooks, D.J., J.A. Ferrante, J. Haverkamp, I. Bowles, W. Lange, and D. Darr, 2001, Economic and Environmental Effects of Accelerated Tariff Liberalization $n$ the Forest Products Sector, Northwest Research Station, Forest Service, USDA.

Chakrabarti, Avik, 2000, "Do Nations That Trade More Have a More Unequal Distribution of Income?" Journal of Economic Development, Dec.

Chaudhuri, Shubham, and Alexander Pfaff, 2002, "Economic Growth and the Environment: What Can We Learn from Household Data?" Columbia University, February. 
Copeland, Brian, and M. Scott Taylor, 1994, "North-South Trade and the Environment," Quarterly Journal of Economics 109, 755-787.

Copeland, Brian, and M. Scott Taylor, 1995, Trade and the Environment: A Partial Synthesis," American Journal of Agricultural Economics 77, 765-771.

Copeland, Brian, and M. Scott Taylor, 2001, "International Trade and the Environment: A Framework for Analysis," NBER Working Paper No. 8540, Oct.

Cropper, Maureen and Charles Griffiths. 1994. "The Interaction of Population Growth and Environmental Quality." American Economic Review, AEA Papers and Proceedings 84(2): $250-254$.

Daly, Herman, 1993, “The Perils of Free Trade,” Scientific American, Nov., 51-55.

Dua, Andre, and Daniel Esty, 1997, Sustaining the Asia Pacific Miracle: Environmental Protection and Economic Integration, Institute for International Economics: Washington DC.

Eiras, Ana, and Brett Schaefer, 2001, "Trade: The Best Way to Protect the Environment," Backgrounder, The Heritage Foundation no. 1480, September 27.

Eskeland, Gunnar, and Ann Harrison, 2002, "Moving to Greener Pastures?

Multinationals and the Pollution Haven Hypothesis,” NBER WP No. 8888, April.

Esty, Daniel, 2001, "Bridging the Trade-Environment Divide," Journal of Economic Perspectives, Summer 15, no. 3, 113-130.

Esty, Daniel, and Bradford Gentry, 1997, "Foreign Investment, Globalisation, and the Environment," Globalization and the Environment, edited by Tom Jones (Organization for Economic Cooperation and Development: Paris).

Esty, Daniel, and Damien Giradin, 1998, "Environmental Protection and International Competitiveness: A Conceptual Framework," J. of World Trade, 32, no. 3, June, 5-46.

Esty, Daniel, and Michael Porter, 2001, "Measuring National Environmental Performance and Its Determinants," Yale Law School and Harvard Business School, April.

Frankel, Jeffrey, 1990, "Zen and the Art of Modern Macroeconomics: The Search for Perfect Nothingness," in Monetary Policy For a Volatile Global Economy, W. Haraf and T. Willett, eds., American Enterprise Institute, Washington, D.C..

Frankel, Jeffrey, 1997, Regional Trading Blocs in the World Trading System, Institute for International Economics, Washington DC. 
Frankel, Jeffrey, and David Romer, 1999, “Does Trade Cause Growth?” American Economic Review, 89, no. 3, June, 379-399.

Frankel, Jeffrey, and Andrew Rose, 2002. "An Estimate of the Effect of Common Currencies on Trade and Income," Quarterly Journal of Economics, May.

Grossman, Gene, and Alan Krueger, 1993, "Environmental Impacts of a North American Free Trade Agreement," in The U.S.-Mexico Free Trade Agreement, Peter Garber, ed., Cambridge MA, MIT Press.

Grossman, Gene, and Alan Krueger, 1995, "Economic Growth and the Environment," Quarterly Journal of Economics, 353-377.

Gurkaynak, Refet, and Harry Krashinsky, 2001, "What Does Trade Do? The Effect of Trade on Inequality and Growth," Princeton University, July.

Hall, Robert, and Charles Jones, "Why Do Some Countries Produce So Much More Output per Worker than Others?" Quarterly Journal of Economics, 114, no.1 (Feb. 1999), 83-116.

Harbaugh, William, Arik Levinson, and David Wilson, 2000, "Reexamining the Empirical Evidence for an Environmental Kuznets Curve," NBER W P No. 7711, May.

Harrison, Ann, 1995, "Openness and Growth: A Time-Series, Cross-Country Analysis for Developing Countries," NBER Working Paper No. 5221, August.

Helpman, Elhanan. 1988, "Growth, Technological Progress, and Trade," National Bureau of Economic Research Reprint no. 1145.

Hilton, F.G. Hank, and Arik Levinson, 1998, "Factoring theEnvironmental Kuznets Curve: Evidence from Automotive Lead Emissions," Journal of Environmental Economics and Management 35, 126-141.

Irwin, Douglas, and Marko Tervio "Does Trade Raise Income? Evidence from the Twentieth Century," NBER Working Paper 7745 (2000).

Jaeger, William, and Van Kolpin, 2000, "Economic Growth and Environmental Resource Allocation," August.

Jaffe, Adam, S. Peterson, Paul Portney and Robert Stavins, 1995, "Environmental Regulation and the Competitiveness of U.S. Manufacturing: What Does the Evidence Tell Us?" Journal of Economic Literature.

Levine, Ross, and David Renelt, 1992, "A Sensitivity Analysis of Cross-Country Growth Regressions," American Economic Review 82, no. 4, 942-963. 
Levinson, Arik, and M. Scott Taylor, 2001, "Trade and the Environment: Unmasking the Pollution Haven Effect," Georgetown University and University of Wisconsin.

Liddle, Brantley, 2001, "Free Trade and the Environment-Development System," Ecological Economics 39, 21-36.

Low, P., and A. Yeats, 1992, "Do 'Dirty' Industries Migrate?" in P. Low, ed., International Trade and the Environment, World Bank, 1992, 89-104.

Mankiw, N. Gregory, David Romer and David Weil, 1992, "A Contribution to the Empirics of Economic Growth," Quarterly Journal of Economics CVII, 407-437, 1992.

Marshall, Monty, and Keith Jaggers, 2000, "Political Regime Characteristics and Transitions, 1800-1999: Dataset Users Manual," Polity IV Project, University of Maryland, College Park; www.bsos.umd.edu/cidcm/inscr/polity.

Meadows, Donella, Dennis Meadows, Jorgen Randers, and William Behrens, 1972, The Limits to Growth, Universe Books, New York.

Muradian, Roldan, Martin O'Connor and Joan Martinez-Alier, 2001, "Embodied Pollution in Trade: Estimating the 'Environmental Load Displacement' of Industrialised Countries," FEEM Working Paper No. 57, July, Milan.

Panayotou, Theo, 1993, "Empirical Tests and Policy Analysis of Environmental Degradtion at Different Stages of Development," Working Paper WP238, Technology and Employment Programme (International Labor Office: Geneva).

Pfaff, Alexander, and Shubham Chaudhuri, "Household Income, Fuel Choice and Indoor Air Quality: Microfoundations of an Environmental Kuznets Curve," Columbia University.

Porter, Michael, 1998, The Competitive Advantage of Nations (The Free Press, MacMillan).

Porter, Michael, and Claas van der Linde, 1995, "Toward a New Conception of the Environment-Competitiveness Relationship," Journal of Economic Perspectives 9, No. 4.

Rodrik, Dani, 1995, "Getting Interventions Right: How South Korea and Taiwan Grew Rich," NBER Working Paper No. 4964; Economic Policy, no. 20.

Rodríguez, Francisco, and Dani Rodrik, "Trade Policy and Economic Growth: A Skeptic's Guide to the Cross-National Evidence," NBER Macroeconomics Annual 2001 (Cambridge, MA: MIT Press, 2001).

Rodrik, Dani, 2000, "Comment on Frankel and Rose," unpublished, Kennedy School of Government, Harvard University. 
Ruggie, John, 1982, "International Regimes, Transactions, and Change: Embedded Liberalism in the Postwar Economic Order," International Organization 36, Spring.

Sala-i-Martin, Xavier, 1991, "Comment," NBER Macroeconomics Annual 6, 368-378.

Schmalensee, R., T. M. Stoker and R.A.Judson, 1996, "World Carbon Dioxide Emissions: 1950-2050," Review of Economics and Statistics, forthcoming.

Selden, Thomas, and Daqing Song, 1994, "Environmental Quality and Development: Is There a Kuznets Curve for Air Pollution Emissions," Journal of Environmental Economics and Management 27, 147-162.

Selden, Thomas, and Daqing Song, 1995, "Neoclassical Growth, the J Curve for Abatement, and the Inverted U Curve for Pollution," Journal of Environmental Economics and Management 29, 162-168.

Shafik, Nemat, 1994, "Economic Development and Environmental Quality: An Econometric Analysis," Oxford Economic Papers 46, 757-773.

Smarzynska, Beata, and Shang-Jin Wei, 2001, "Pollution Havens and Foreign Direct Investment: Dirty Secret or Popular Myth?" NBER Working Paper No. 8465, September.

Solow, Robert, 1956 “A Contribution to the Theory of Economic Growth,” Quarterly Journal of Economics 70, February, 65-94.

Stokey, Nancy, 1998, “Are There Limits to Growth?” International Economic Review 39, no. 1, February, 1-31.

Suri, Vivek, and Duane Chapman, 1998, "Economic Growth, Trade and Energy:

Implications for the Environmental Kuznets Curve," Ecological Economics 25, 2, May, 147-160.

Tobey, James A., 1990, “The Effects of Domestic Environmental Policies on Patterns of World Trade: An Empirical Test," Kyklos 43, 191-209.

Vogel, David, 1995, Trading Up: Consumer and Environmental Regulation in a Global Economy, Harvard University Press.

World Bank, 1992, Development and the Environment, World Development Report (Oxford University Press: NY). 


\section{Table 1: Income equations}

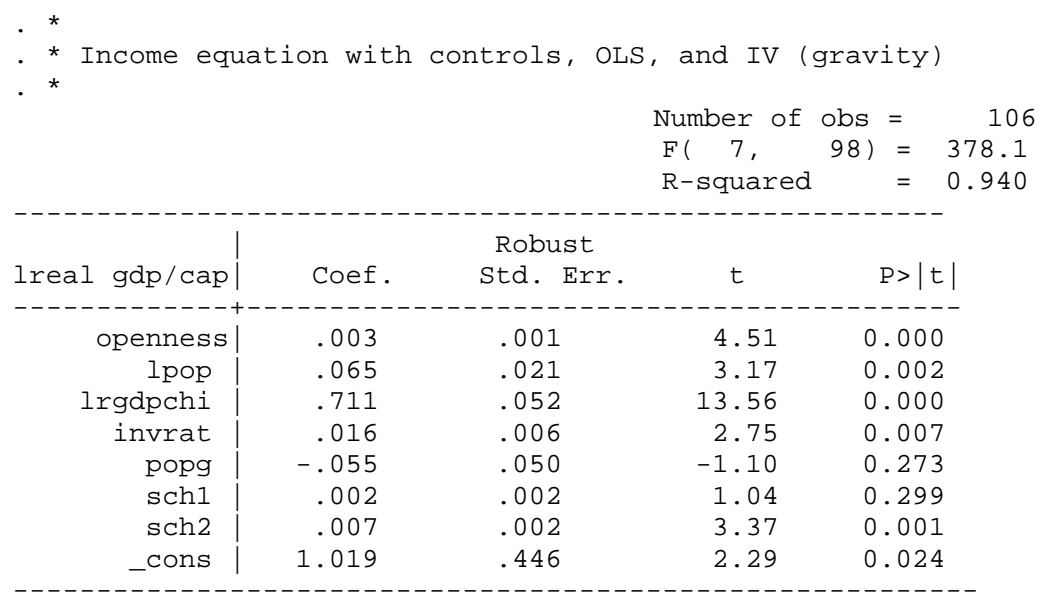

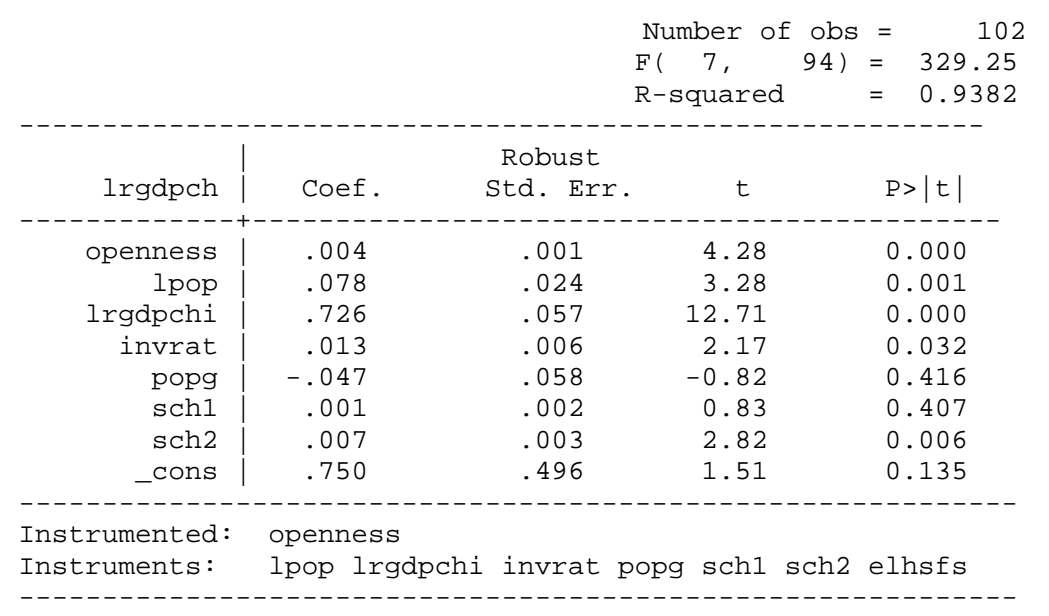

\section{Table 2:}

Air pollution equations - OLS (with quadratic income)

.$*$
.$*$ NO2
OLS regression

. * Income Peak 7665.0902 


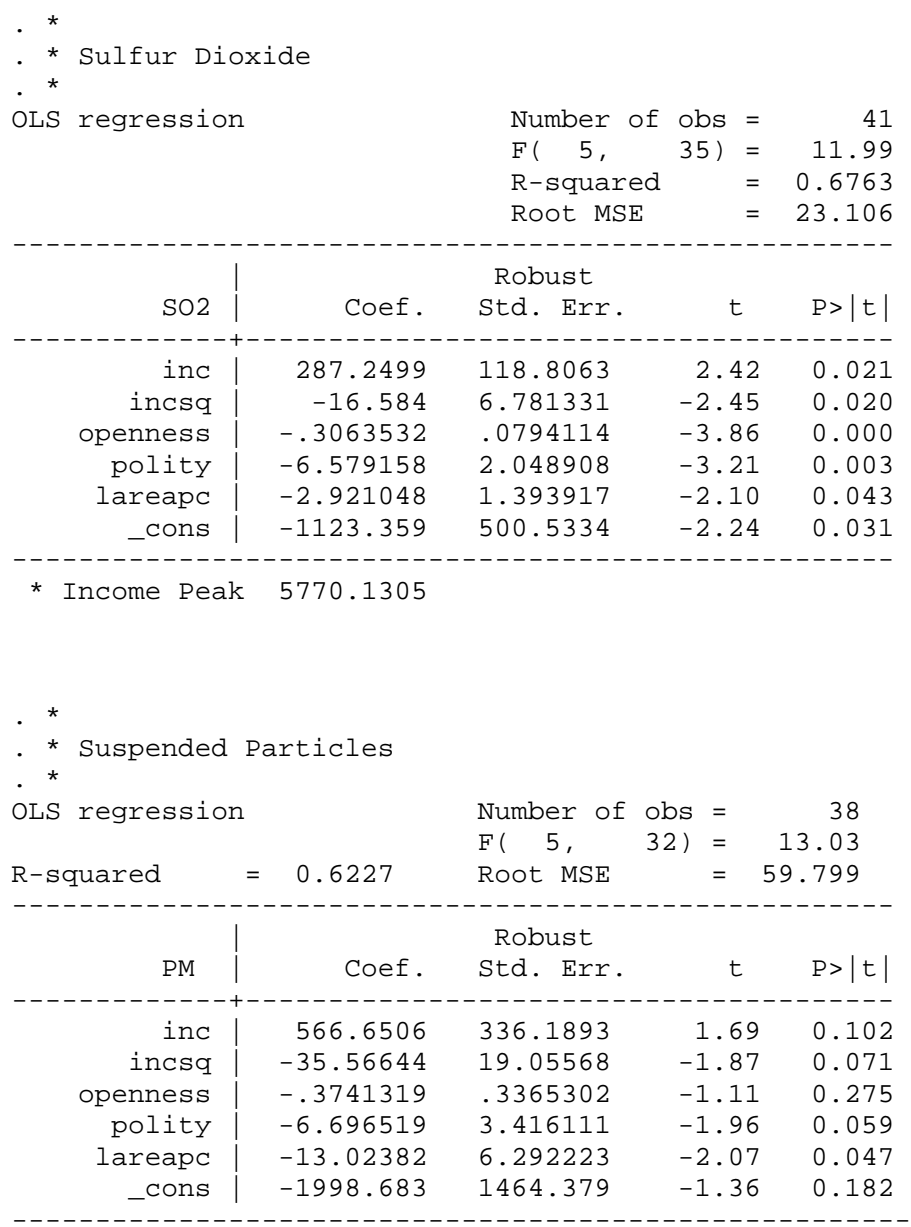

. * Income Peak 2881.5566

\section{Table 3:}

\section{Air pollution equations - IV (with quadratic income)}

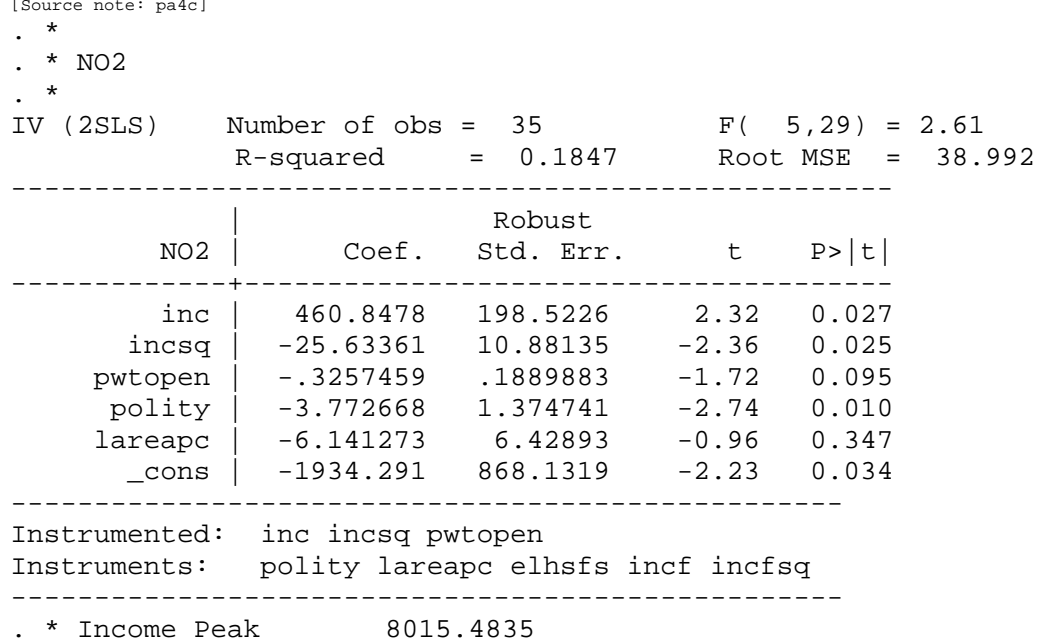




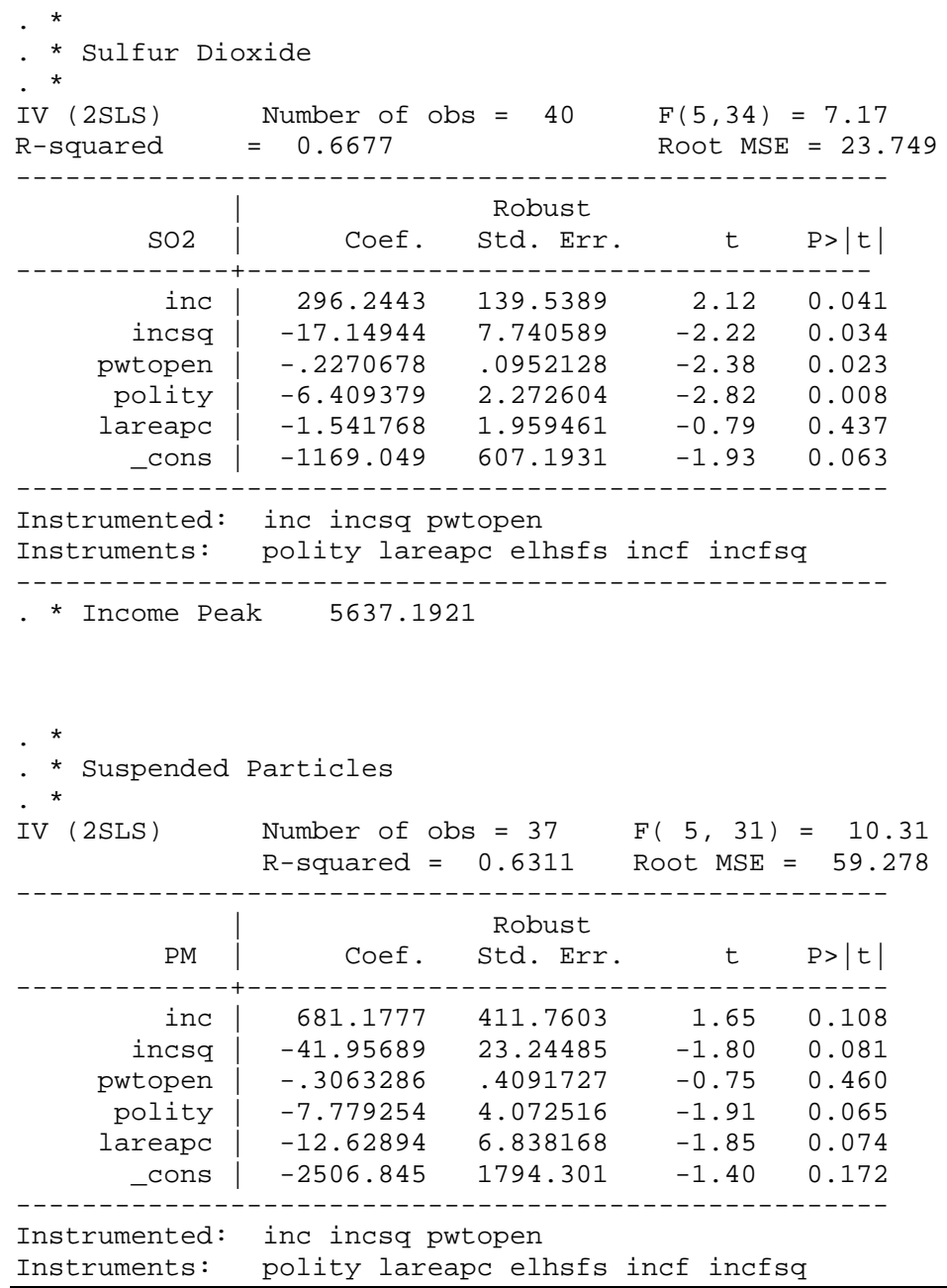

\section{Table 4: Other environmental degradation equations--} OLS (with quadratic income)

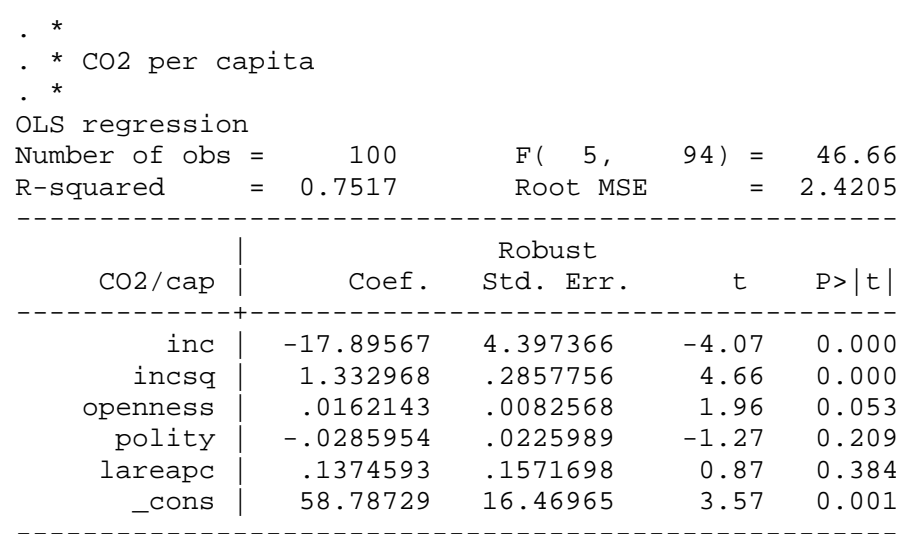

. * Income Flat $\quad 822.80085$ 


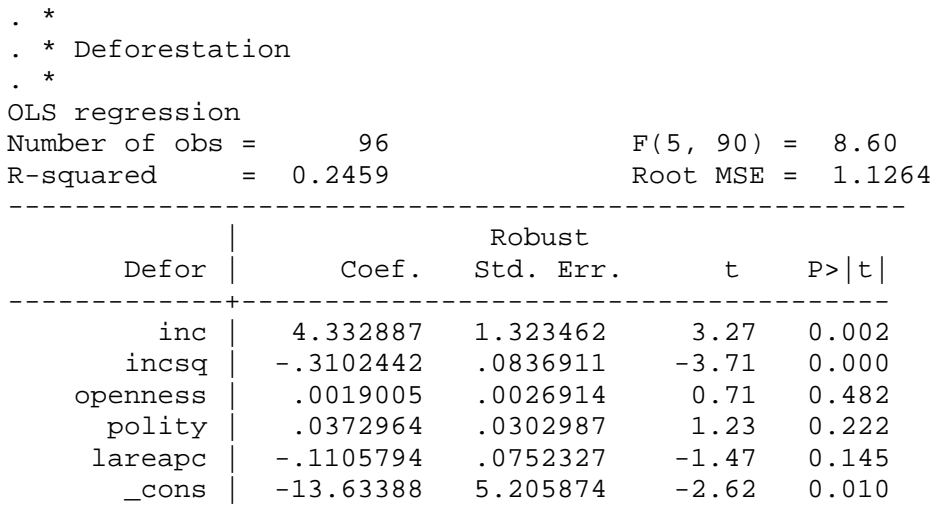

. Income Peak 1078.177

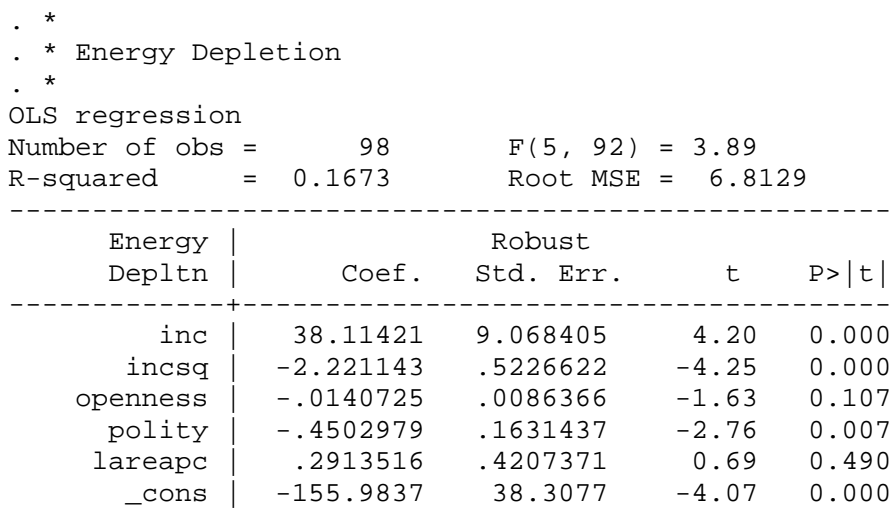

. * Income Flat 5323.3903

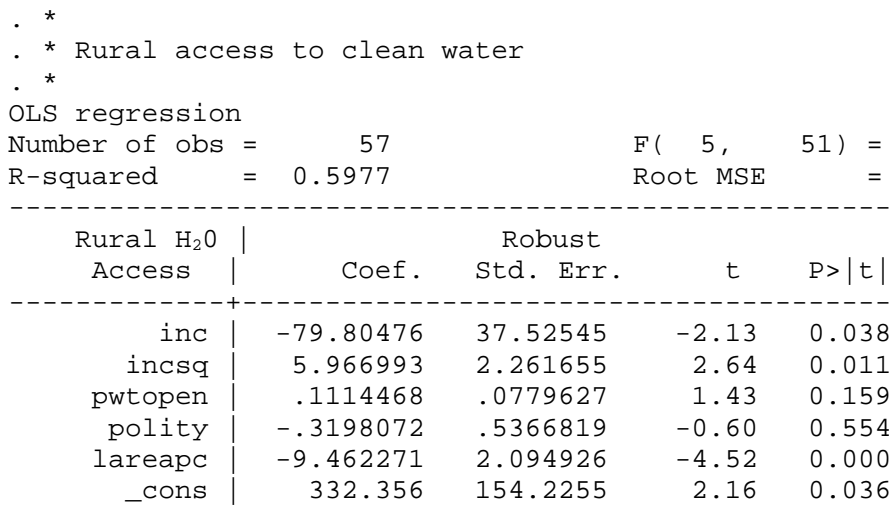

. * Income Peak $\quad 802.06048$ 


\section{Table 5: Other environmental degradation equations -- IV (with quadratic income)}

\begin{tabular}{|c|c|c|c|c|}
\hline IV (2SLS) & $\begin{array}{l}\text { Number of ob } \\
R \text {-squared }=\end{array}$ & $\begin{array}{l}s=96 \\
0.7712\end{array}$ & $\begin{array}{l}\mathrm{F}(5,90)= \\
\text { Root MSE }=\end{array}$ & $\begin{array}{r}=51.90 \\
=\quad 2.0875\end{array}$ \\
\hline $\mathrm{co} 2 / \mathrm{cap}$ & Coef. & $\begin{array}{l}\text { Robust } \\
\text { Std. Err. }\end{array}$ & $t$ & $P>|t|$ \\
\hline $\begin{array}{r}\text { inc } \\
\text { incsq } \\
\text { pwtopen } \\
\text { polity } \\
\text { lareapc } \\
\text { _cons }\end{array}$ & $\begin{array}{r}-15.62027 \\
1.210887 \\
.0001553 \\
-.083874 \\
.0186855 \\
49.92776\end{array}$ & $\begin{array}{r}3.790209 \\
.2490011 \\
.0100028 \\
.0354992 \\
.1594831 \\
14.25378\end{array}$ & $\begin{array}{r}-4.12 \\
4.86 \\
0.02 \\
-2.36 \\
0.12 \\
3.50\end{array}$ & $\begin{array}{l}0.000 \\
0.000 \\
0.988 \\
0.020 \\
0.907 \\
0.001\end{array}$ \\
\hline $\begin{array}{l}\text { Instrumented: } \\
\text { Instruments: }\end{array}$ & $\begin{array}{l}\text { inc incsq pr } \\
\text { polity lare }\end{array}$ & $\begin{array}{l}\text { wtopen } \\
\text { apc elhsfs }\end{array}$ & incf incfsc & \\
\hline
\end{tabular}

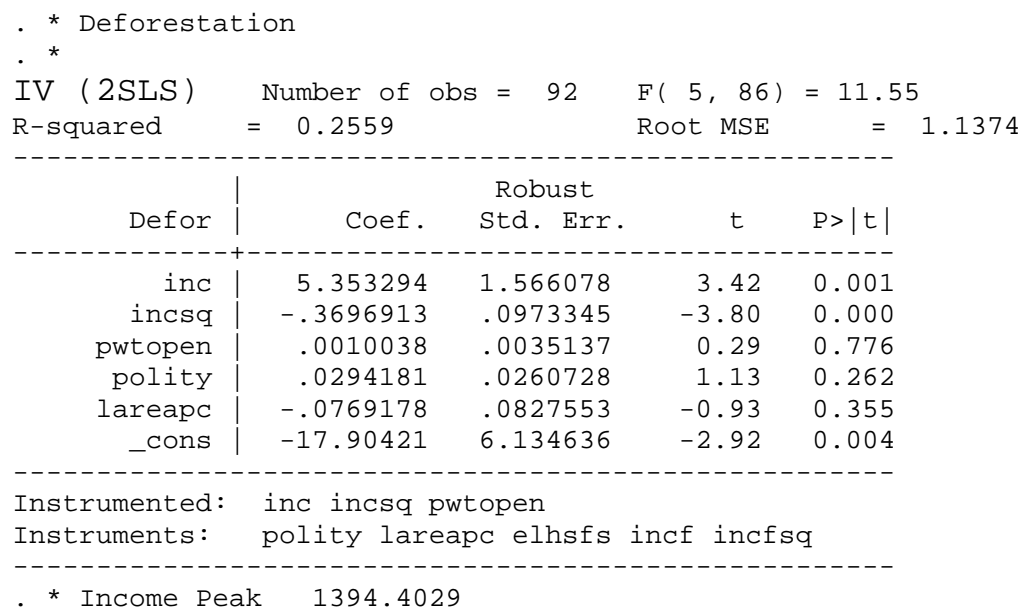

\begin{tabular}{|c|c|c|c|c|}
\hline IV $\quad(2 \mathrm{SLS})$ & $\begin{array}{l}\text { Number of obs } \\
\text { R-squared }=\end{array}$ & $\begin{array}{l}=93 \\
0.1644\end{array}$ & $\begin{array}{l}\mathrm{F}(5,87) \\
\text { Root } \mathrm{MSE}=\end{array}$ & $\begin{aligned}= & 4.30 \\
& 6.9883\end{aligned}$ \\
\hline $\begin{array}{l}\text { Energy } \\
\text { Depltn }\end{array}$ & Coef. & $\begin{array}{l}\text { Robust } \\
\text { Std. Err. }\end{array}$ & $t$ & $\mathrm{P}>|\mathrm{t}|$ \\
\hline $\begin{array}{r}\text { inc } \\
\text { incsq } \\
\text { pwtopen } \\
\text { polity } \\
\text { lareapc } \\
\text { _cons }\end{array}$ & $\begin{array}{r}43.3005 \\
-2.510521 \\
-.0342903 \\
-.5218554 \\
.3640927 \\
-177.1147\end{array}$ & $\begin{array}{r}9.624654 \\
.5576702 \\
.0195457 \\
.1813587 \\
.5103971 \\
39.62378\end{array}$ & $\begin{array}{r}4.50 \\
-4.50 \\
-1.75 \\
-2.88 \\
0.71 \\
-4.47\end{array}$ & $\begin{array}{l}0.000 \\
0.000 \\
0.083 \\
0.005 \\
0.478 \\
0.000\end{array}$ \\
\hline $\begin{array}{l}\text { Instrumented: } \\
\text { Instruments: }\end{array}$ & $\begin{array}{l}\text { inc incsq pw } \\
\text { polity larea }\end{array}$ & $\begin{array}{l}\text { wtopen } \\
\text { apc elhsfs }\end{array}$ & incf incfsc & \\
\hline
\end{tabular}




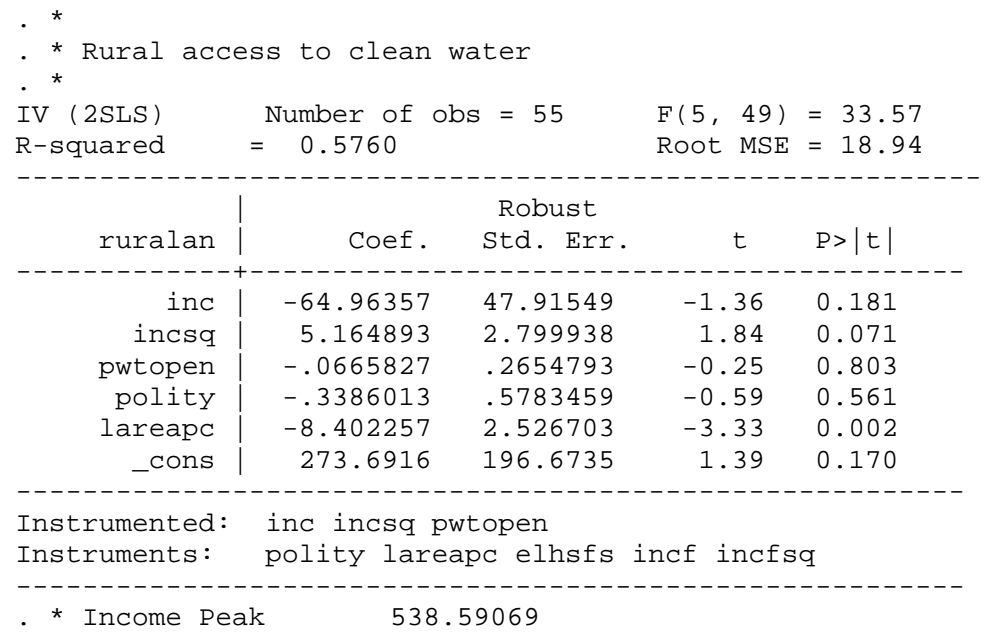

\section{Table 6: Does openness lead poor countries to exploit} a comparative advantage in pollution?

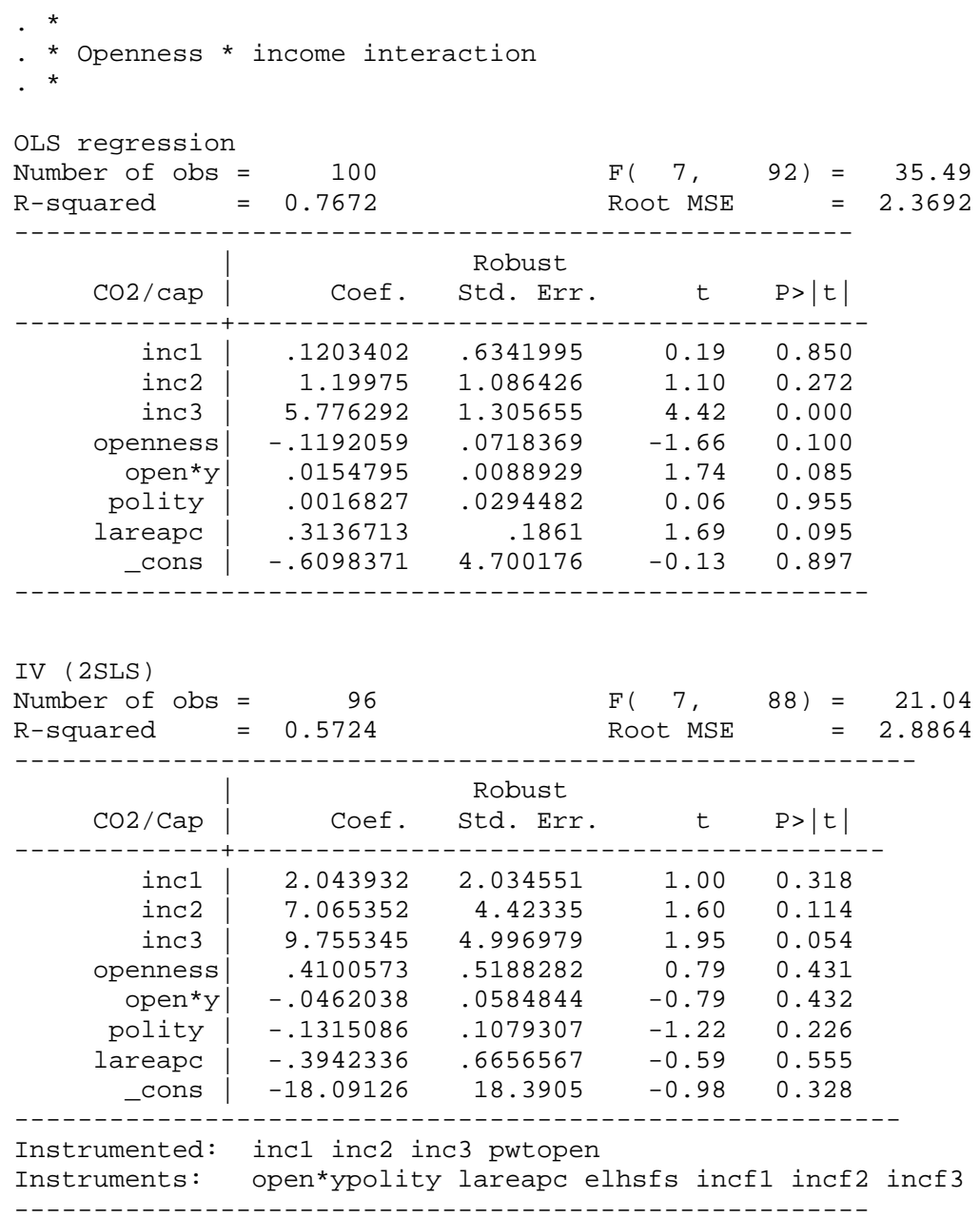




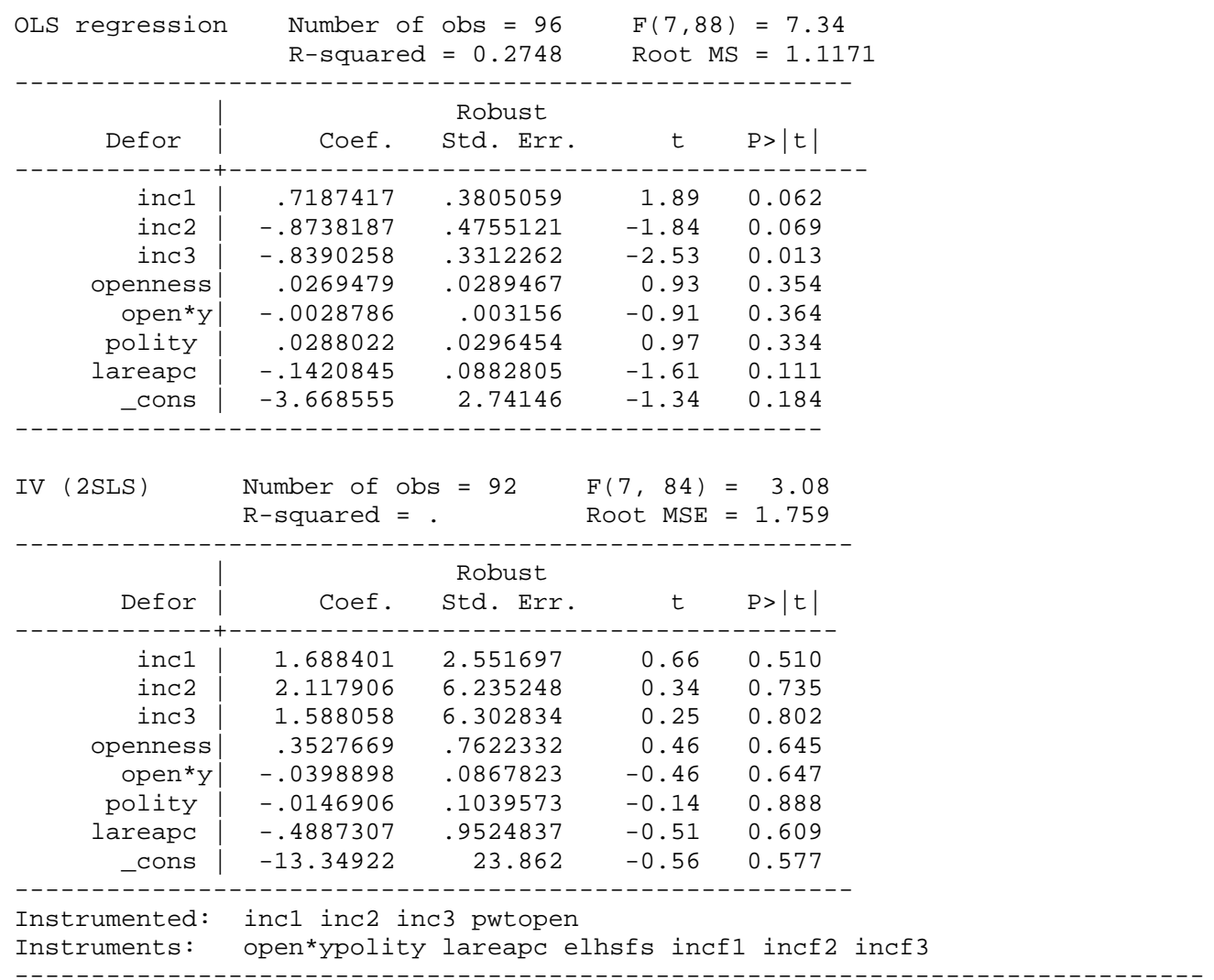

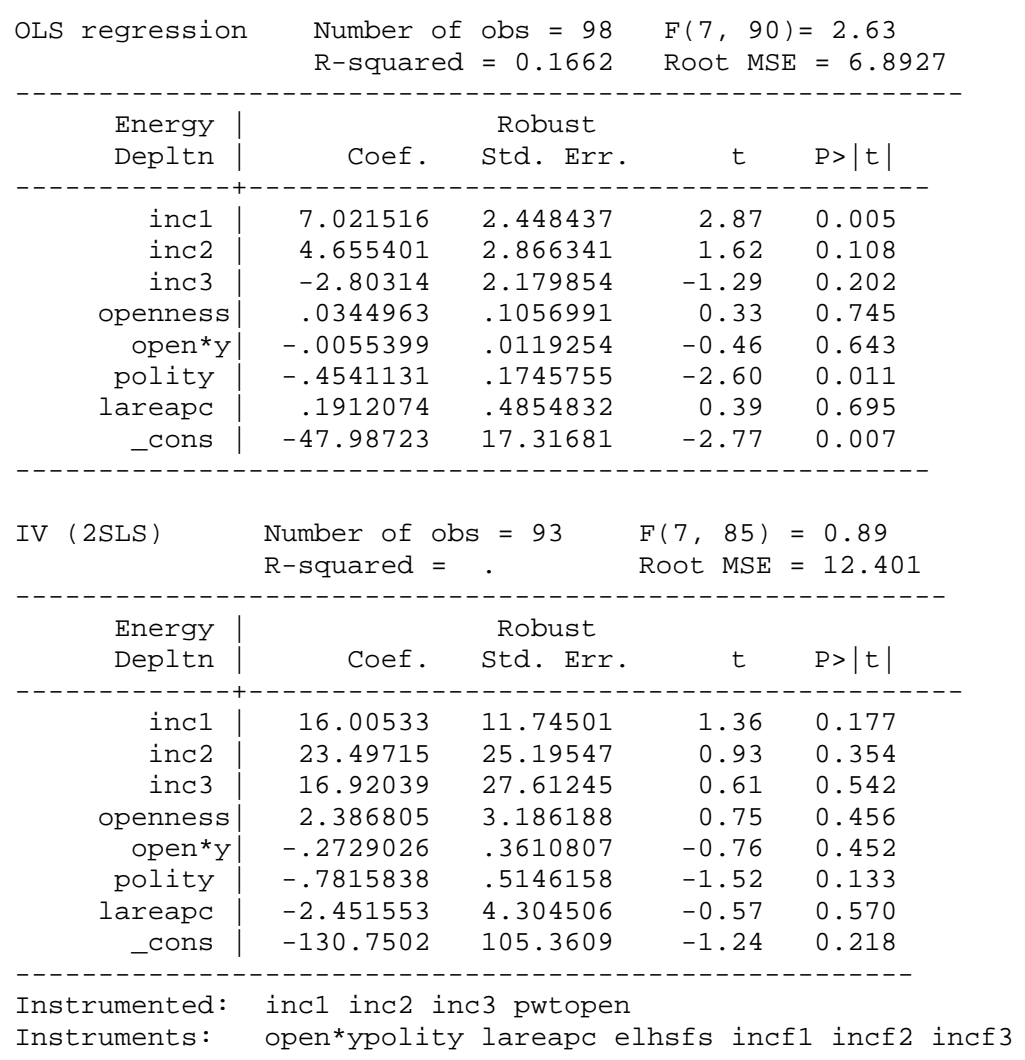




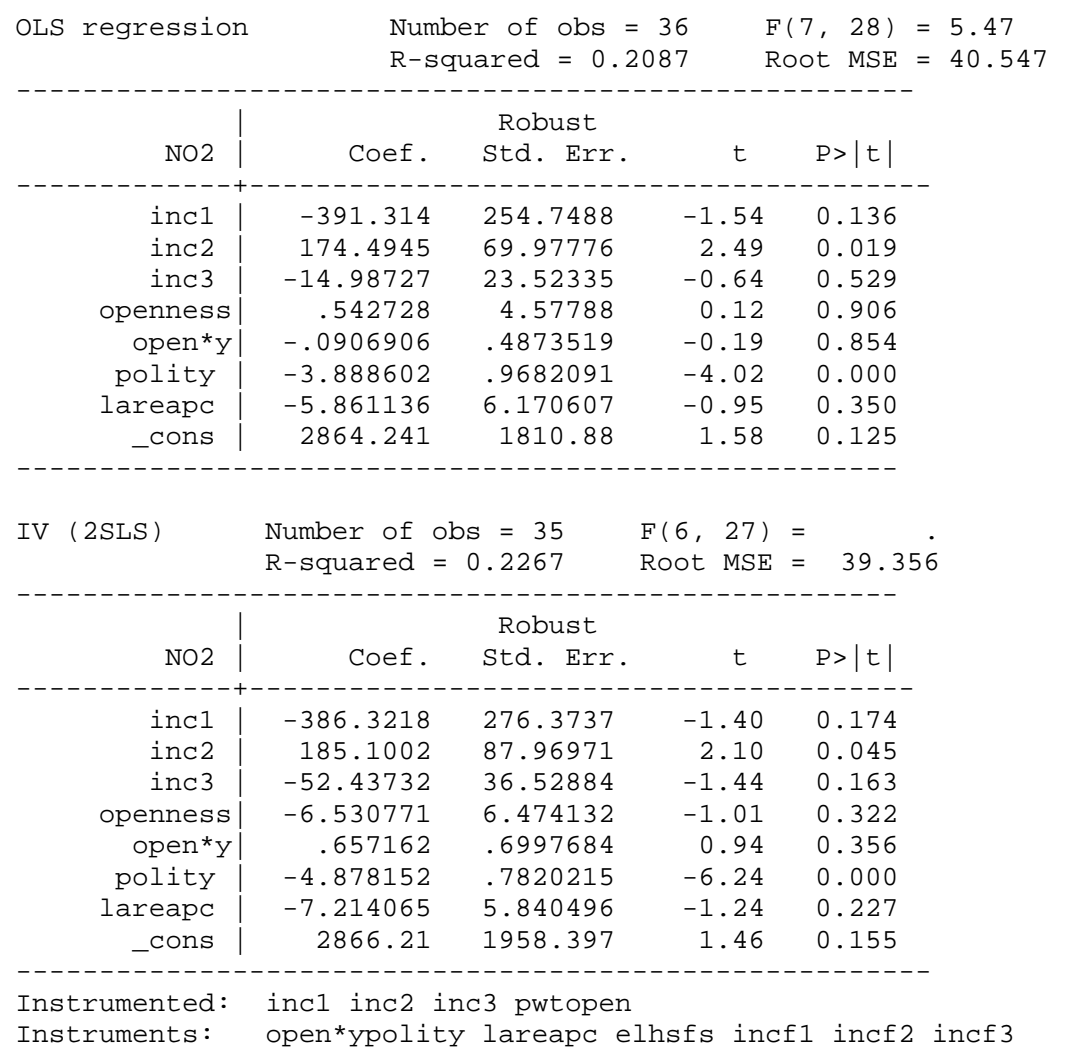

\begin{tabular}{|c|c|c|c|c|c|}
\hline OLS & regression & $\begin{array}{l}\text { Numb } \\
\mathrm{R}-\mathrm{sc}\end{array}$ & $\begin{array}{l}\text { er of obs }= \\
\text { uared }=0.7\end{array}$ & $\begin{array}{r}=41 \\
7275\end{array}$ & $\begin{array}{l}(7,33)=84.38 \\
\text { oot MSE }=21.834\end{array}$ \\
\hline & $\mathrm{SO} 2$ & Coef. & $\begin{array}{l}\text { Robust } \\
\text { Std. Err. }\end{array}$ & $t$ & $P>|t|$ \\
\hline & $\begin{array}{c}\text { inc1 } \\
\text { inc2 } \\
\text { inc3 } \\
\text { openness } \\
\text { open*y } \\
\text { polity } \\
\text { lareapc } \\
\text { _cons }\end{array}$ & $\begin{array}{r}155.3254 \\
.5225823 \\
-46.77605 \\
-4.76608 \\
.4837392 \\
-6.15931 \\
-2.316554 \\
-1009.304\end{array}$ & $\begin{array}{r}94.3227 \\
20.25033 \\
15.7941 \\
2.187854 \\
.2323481 \\
1.80856 \\
1.626319 \\
665.3372\end{array}$ & $\begin{array}{r}1.65 \\
0.03 \\
-2.96 \\
-2.18 \\
2.08 \\
-3.41 \\
-1.42 \\
-1.52\end{array}$ & $\begin{array}{l}0.109 \\
0.980 \\
0.006 \\
0.037 \\
0.045 \\
0.002 \\
0.164 \\
0.139\end{array}$ \\
\hline IV & (2SLS) & $\begin{array}{l}\text { Number of } 0 \\
\text { R-squared }=\end{array}$ & $\begin{array}{l}S=40 \\
0.7297\end{array}$ & $\begin{array}{l}F(7,32)= \\
\text { Root MSE }=\end{array}$ & $\begin{array}{l}=8.89 \\
=22.075\end{array}$ \\
\hline & $\mathrm{SO} 2$ & Coef. & $\begin{array}{l}\text { Robust } \\
\text { Std. Err. }\end{array}$ & $t$ & $P>|t|$ \\
\hline & $\begin{array}{c}\text { inc1 } \\
\text { inc2 } \\
\text { inc3 } \\
\text { openness } \\
\text { open*y } \\
\text { polity } \\
\text { lareapc } \\
\text { _cons }\end{array}$ & $\begin{array}{r}191.0826 \\
-3.533549 \\
-67.68094 \\
-7.805166 \\
.8083979 \\
-6.340865 \\
-2.270977 \\
-1249.701\end{array}$ & $\begin{array}{l}152.0559 \\
46.19984 \\
32.24662 \\
4.571801 \\
.4891454 \\
1.855417 \\
1.990991 \\
1085.205\end{array}$ & $\begin{array}{r}1.26 \\
-0.08 \\
-2.10 \\
-1.71 \\
1.65 \\
-3.42 \\
-1.14 \\
-1.15\end{array}$ & $\begin{array}{l}0.218 \\
0.940 \\
0.044 \\
0.097 \\
0.108 \\
0.002 \\
0.262 \\
0.258\end{array}$ \\
\hline $\begin{array}{l}\text { Ins } \\
\text { Ins }\end{array}$ & $\begin{array}{l}\text { trumented: } \\
\text { truments: }\end{array}$ & $\begin{array}{l}\text { inc1 inc2 i } \\
\text { open*ypolit }\end{array}$ & $\begin{array}{l}\text { c3 pwtopen } \\
\text { lareapc e }\end{array}$ & Ihsfs incf & $f 1$ incf 2 incf 3 \\
\hline
\end{tabular}




\begin{tabular}{|c|c|c|c|c|c|}
\hline $\begin{array}{l}\text { OLS regressio } \\
\text { Number of obs } \\
\text { R-squared }\end{array}$ & $\begin{array}{rr}= & 38 \\
= & 0.7438\end{array}$ & & $\begin{array}{l}\text { F ( 7, } \\
\text { Root MSE }\end{array}$ & 30) & $\begin{array}{r}14.75 \\
50.896\end{array}$ \\
\hline PM & Coef. & $\begin{array}{l}\text { Robust } \\
\text { Std. Err. }\end{array}$ & t & $P>|t|$ & \\
\hline inc1 & 302.4914 & 78.65209 & 3.85 & 0.001 & \\
\hline inc2 & $-143 \cdot 3542$ & 51.88573 & -2.76 & 0.010 & \\
\hline inc 3 & -98.09078 & 33.43229 & -2.93 & 0.006 & \\
\hline openness & -7.812377 & 3.700031 & -2.11 & 0.043 & \\
\hline open* ${ }^{*}$ & .8556435 & .401887 & 2.13 & 0.042 & \\
\hline polity & -7.781859 & 2.882361 & -2.70 & 0.011 & \\
\hline lareapc & -8.695255 & 4.412314 & -1.97 & 0.058 & \\
\hline _cons & -1859.638 & 571.4924 & -3.25 & 0.003 & \\
\hline
\end{tabular}

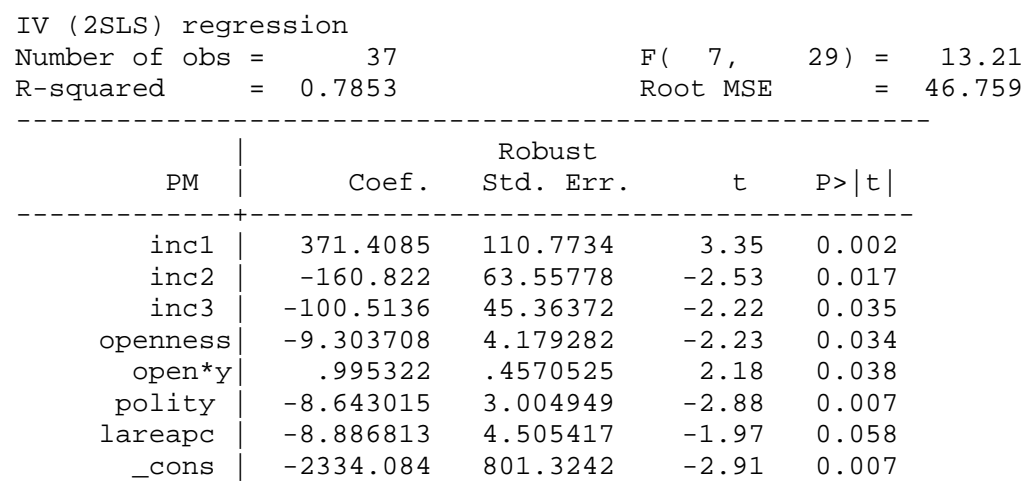

Instrumented: inc1 inc2 inc3 pwtopen

Instruments: open*ypolity lareapc elhsfs incf1 incf2 incf3

\section{Table 7: Does openness lead sparsely populated countries to exploit a comparative advantage in pollution?}

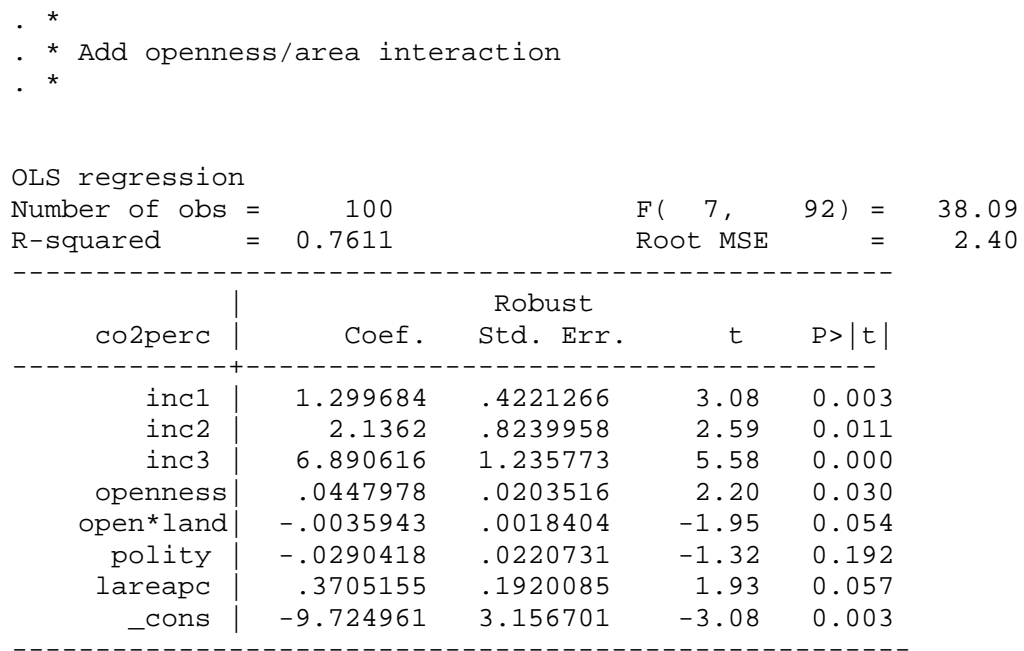




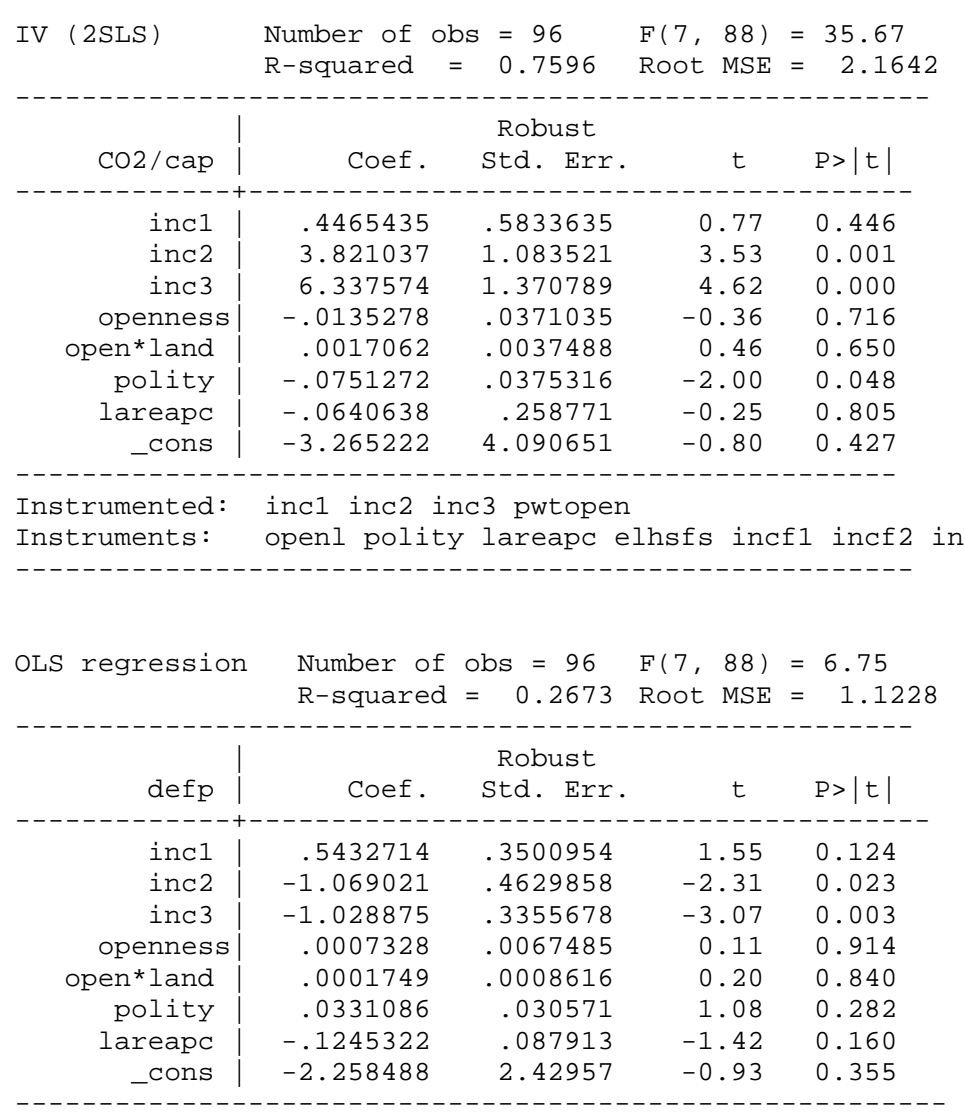

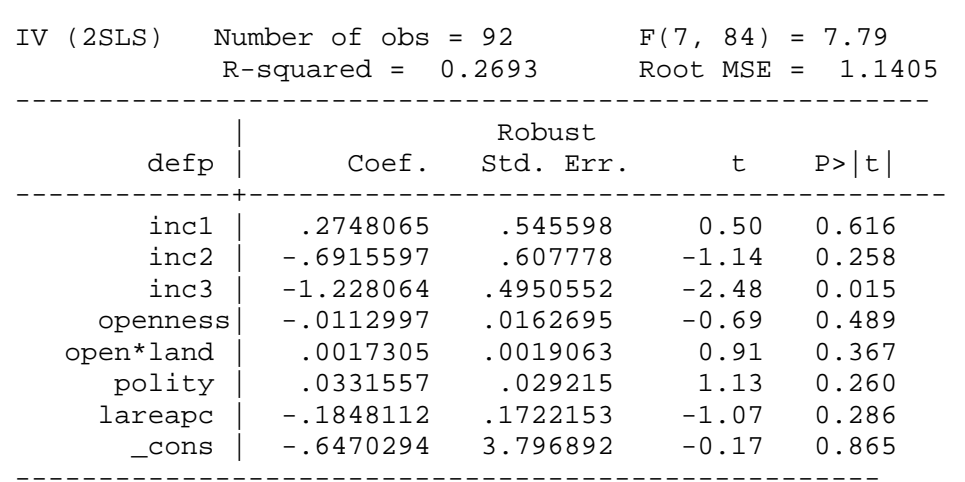

Instrumented: inc1 inc2 inc3 pwtopen

Instruments: openl polity lareapc elhsfs incfl incf2 incf3

\begin{tabular}{|c|c|c|c|c|}
\hline OLS regression & $\begin{array}{l}\text { Number of } \\
\text { R-squared }\end{array}$ & $\begin{array}{l}\text { obs }=98 \\
=\quad 0.1747\end{array}$ & $\begin{array}{l}\text { F }(7,90) \\
\text { Root MSE }\end{array}$ & $\begin{array}{l}=2.75 \\
=\quad 6.8574\end{array}$ \\
\hline enrdam & Coef. & $\begin{array}{l}\text { Robust } \\
\text { Std. Err. }\end{array}$ & $t$ & $P>|t|$ \\
\hline inc1 & 6.301647 & 2.235743 & 2.82 & 0.006 \\
\hline inc2 & 4.319096 & 2.871935 & 1.50 & 0.136 \\
\hline inc3 & -3.037144 & 1.845817 & -1.65 & 0.103 \\
\hline openness & -.0609797 & .048293 & -1.26 & 0.210 \\
\hline open*land & .0057844 & .0058749 & 0.98 & 0.327 \\
\hline polity & -.4448992 & .1690579 & -2.63 & 0.010 \\
\hline lareapc & -.1398897 & .6781088 & -0.21 & 0.837 \\
\hline _cons & -42.73908 & 15.97659 & -2.68 & 0.009 \\
\hline
\end{tabular}




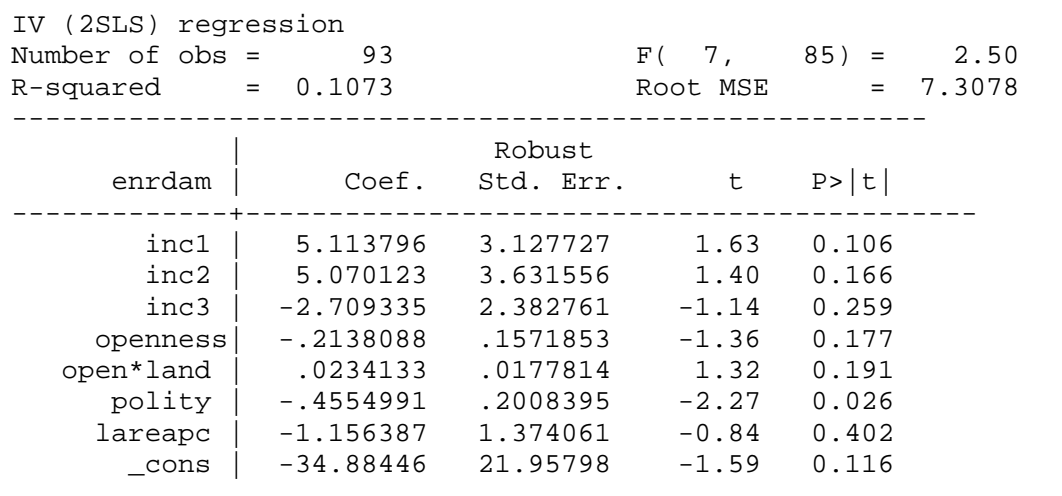

Instrumented: inc1 inc2 inc3 pwtopen

Instruments: openl polity lareapc elhsfs incfl incf2 incf3

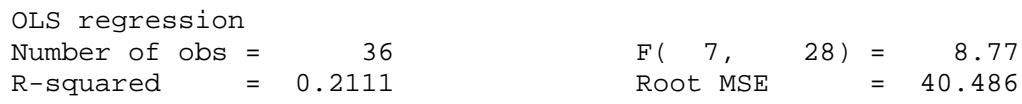

\begin{tabular}{r|rrrr} 
& \multicolumn{4}{|c}{ Robust } \\
no2m & Coef. & Std. Err. & $t$ & $\mathrm{P}>|\mathrm{t}|$ \\
inc1 & -395.9399 & 238.3117 & -1.66 & 0.108 \\
inc2 & 175.4628 & 63.49874 & 2.76 & 0.010 \\
inc3 & -19.44896 & 14.25501 & -1.36 & 0.183 \\
openness & -.4422456 & .2767019 & -1.60 & 0.121 \\
open*land & .0198979 & .0477338 & 0.42 & 0.680 \\
polity & -4.114193 & .974946 & -4.22 & 0.000 \\
lareapc & -6.368941 & 5.84243 & -1.09 & 0.285 \\
_cons & 2899.056 & 1701.499 & 1.70 & 0.099
\end{tabular}

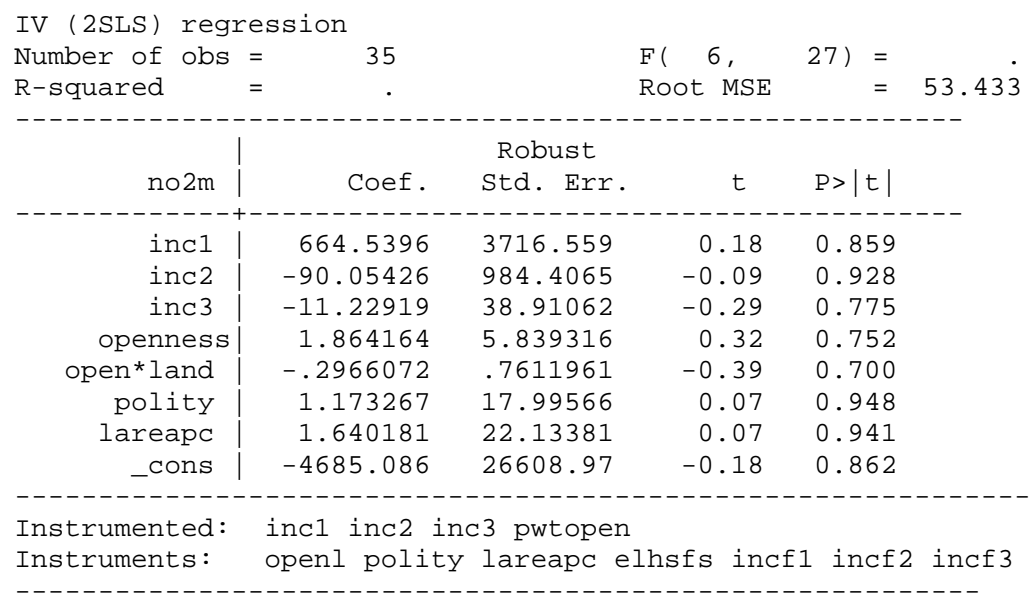




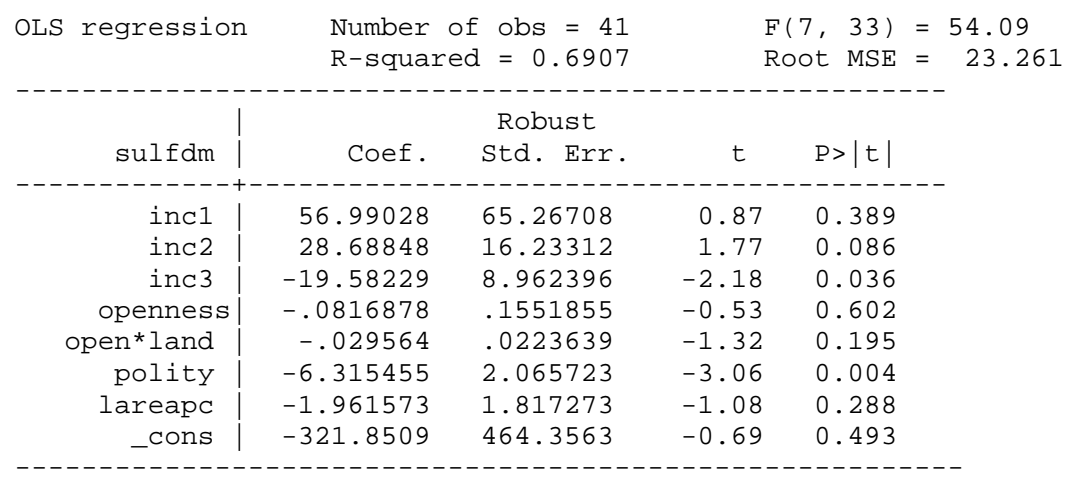

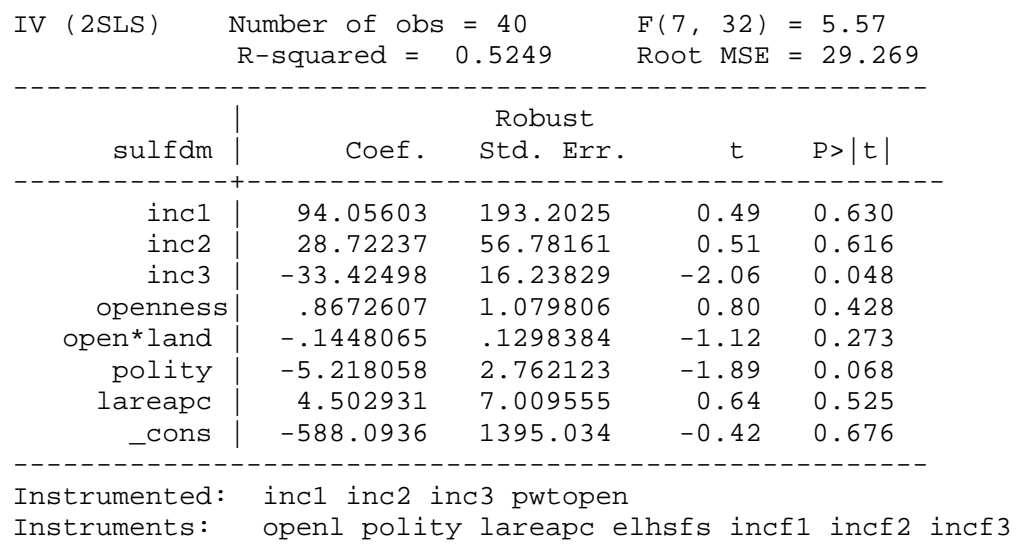

\begin{tabular}{|c|c|c|c|c|c|}
\hline & regression & $\begin{array}{l}\text { Number } \\
\text { R-squar }\end{array}$ & $\begin{array}{l}\text { obs }=38 \\
=0.7156\end{array}$ & $\begin{array}{l}\mathrm{F} \\
\mathrm{R}\end{array}$ & $\begin{array}{l}(7,30)=11.42 \\
\text { oot MSE }=53.623\end{array}$ \\
\hline & suspm & Coef. & $\begin{array}{l}\text { Robust } \\
\text { Std. Err. }\end{array}$ & t & $P>|t|$ \\
\hline & $\begin{array}{r}\text { inc1 } \\
\text { inc2 } \\
\text { inc3 } \\
\text { openness } \\
\text { open*land } \\
\text { polity } \\
\text { lareapc } \\
\text { _cons }\end{array}$ & $\begin{array}{r}340.8696 \\
-115.8087 \\
-47.30731 \\
.2975468 \\
-.0493102 \\
-7.66129 \\
-9.036961 \\
-2187.683\end{array}$ & $\begin{array}{r}105.7901 \\
54.30535 \\
22.7261 \\
1.153204 \\
.0938695 \\
3.572705 \\
5.648587 \\
761.71\end{array}$ & $\begin{array}{r}3.22 \\
-2.13 \\
-2.08 \\
0.26 \\
-0.53 \\
-2.14 \\
-1.60 \\
-2.87\end{array}$ & $\begin{array}{l}0.003 \\
0.041 \\
0.046 \\
0.798 \\
0.603 \\
0.040 \\
0.120 \\
0.007\end{array}$ \\
\hline IV & $\begin{array}{r}\text { (2SLS) } \\
\text { Rumb } \\
\text { R } \mathrm{sq}\end{array}$ & $\begin{array}{l}r \text { of obs }= \\
\text { dared }=0\end{array}$ & 191 & $\begin{array}{ll}\text { F ( } 7, & 29) \\
\text { Root } & \text { MSE }\end{array}$ & $\begin{array}{l}=8.45 \\
=53.486\end{array}$ \\
\hline & suspm & Coef. & $\begin{array}{l}\text { Robust } \\
\text { Std. Err. }\end{array}$ & $t$ & $P>|t|$ \\
\hline & $\begin{array}{r}\text { inc1 } \\
\text { inc2 } \\
\text { inc3 } \\
\text { openness } \\
\text { open*land } \\
\text { polity } \\
\text { lareapc } \\
\text { _cons }\end{array}$ & $\begin{array}{r}515.1731 \\
-169.1569 \\
-35.95014 \\
2.503075 \\
-.2609476 \\
-9.57346 \\
-2.147277 \\
-3419.099\end{array}$ & $\begin{array}{l}127.7988 \\
76.93958 \\
26.73539 \\
1.489398 \\
.1356765 \\
3.991047 \\
6.519563 \\
905.9681\end{array}$ & $\begin{array}{r}4.03 \\
-2.20 \\
-1.34 \\
1.68 \\
-1.92 \\
-2.40 \\
-0.33 \\
-3.77\end{array}$ & $\begin{array}{l}0.000 \\
0.036 \\
0.189 \\
0.104 \\
0.064 \\
0.023 \\
0.744 \\
0.001\end{array}$ \\
\hline $\begin{array}{l}\text { Ins } \\
\text { Ins }\end{array}$ & $\begin{array}{l}\text { trumented: } \\
\text { truments: }\end{array}$ & $\begin{array}{l}\text { incl inc2 i } \\
\text { openl polit }\end{array}$ & $\begin{array}{l}3 \text { pwtopen } \\
\text { lareapc e }\end{array}$ & hsfs inc & $=1$ incf 2 incf 3 \\
\hline
\end{tabular}


Table 8: Does openness lead capital-intensive countries to exploit a comparative advantage in pollution?

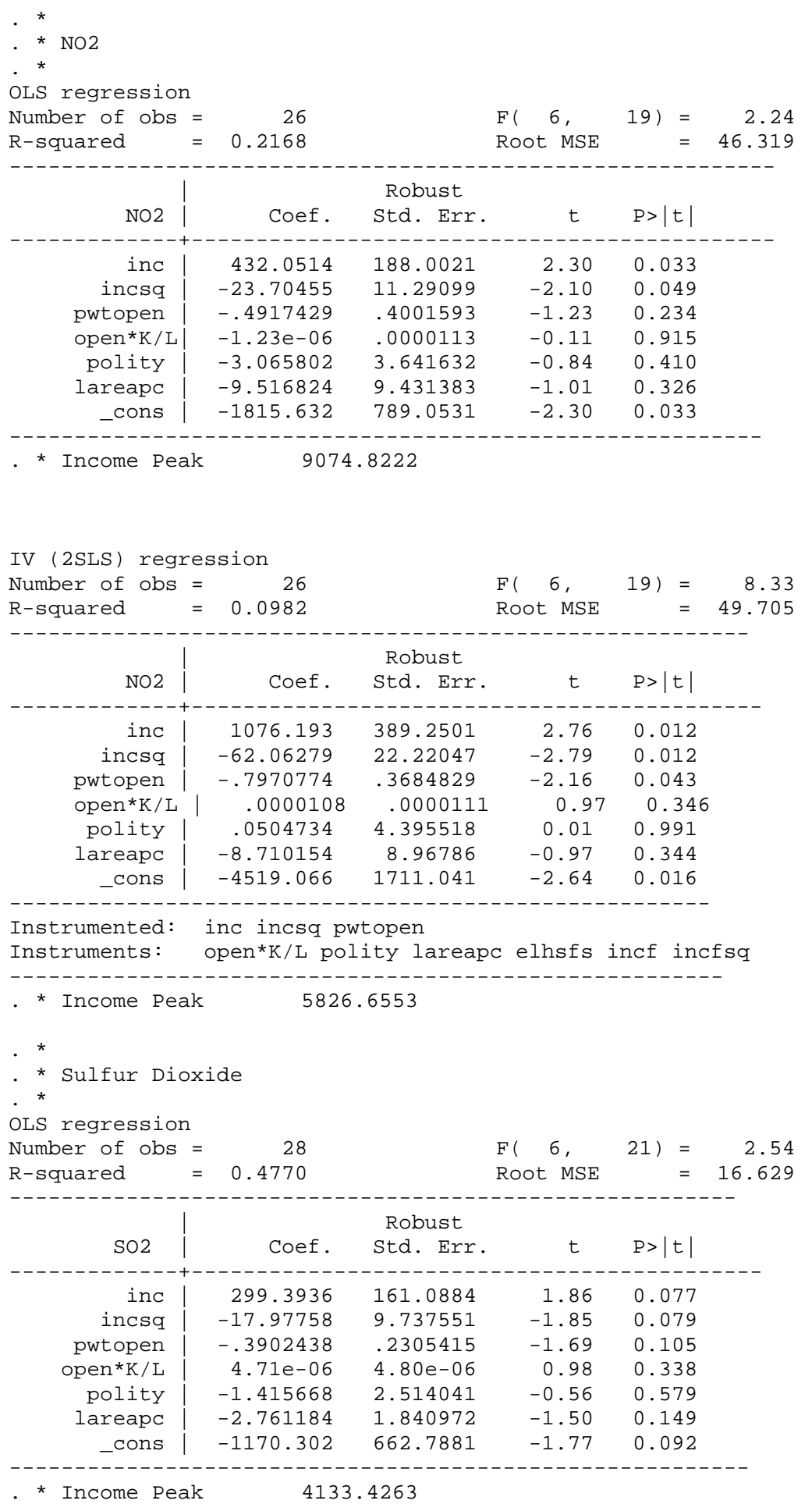




IV (2SLS) regression
$\begin{array}{r}\text { Number of obs }= \\ \text { R-squared }\end{array}=0.3433$
SO2 |

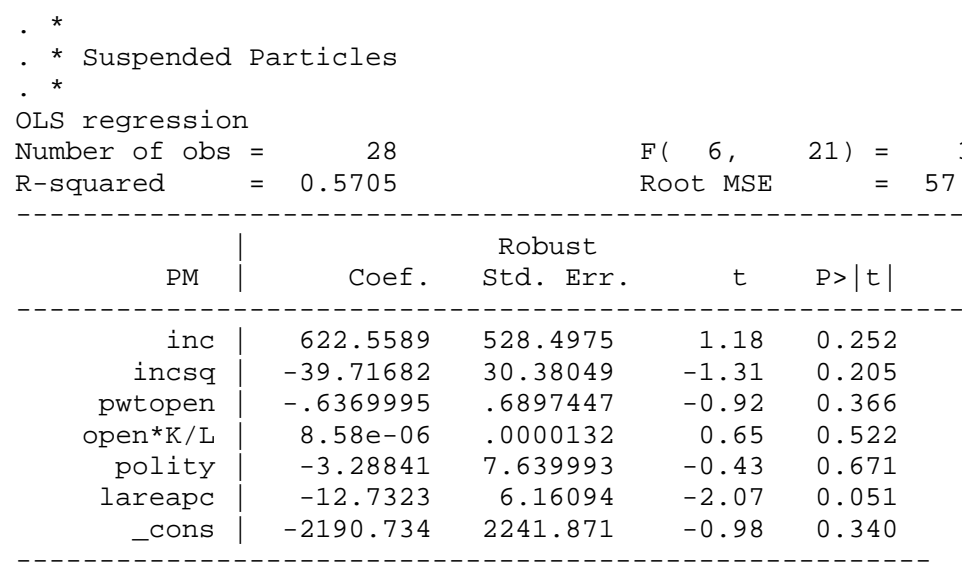

. * Income Peak 2533.7881

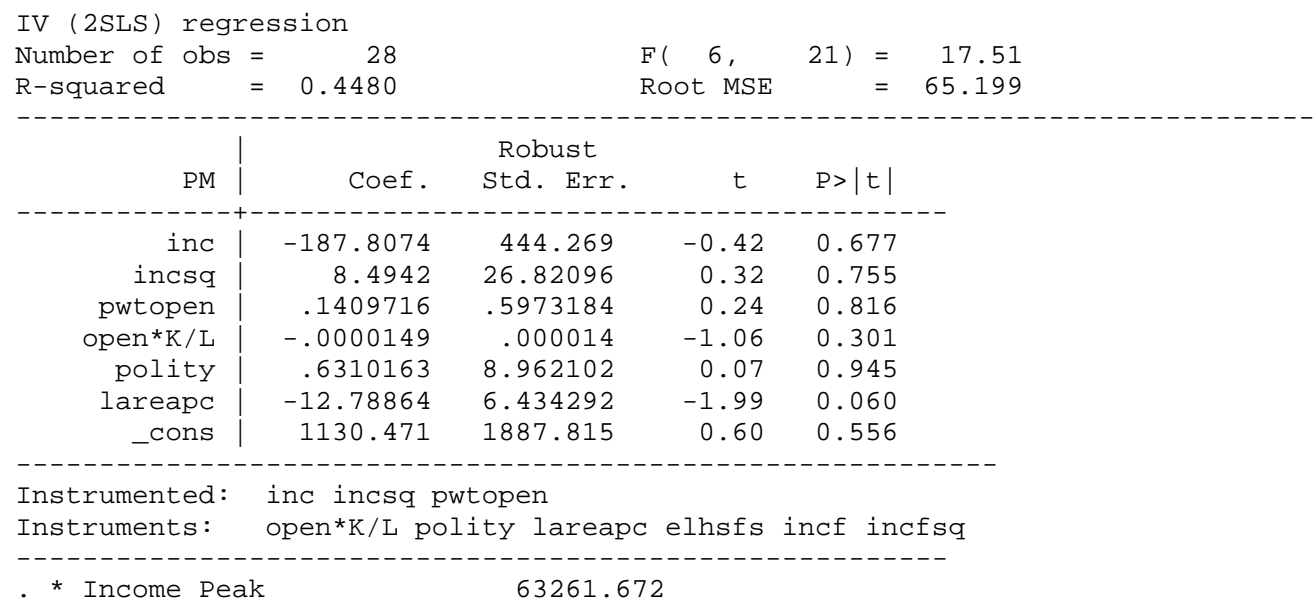




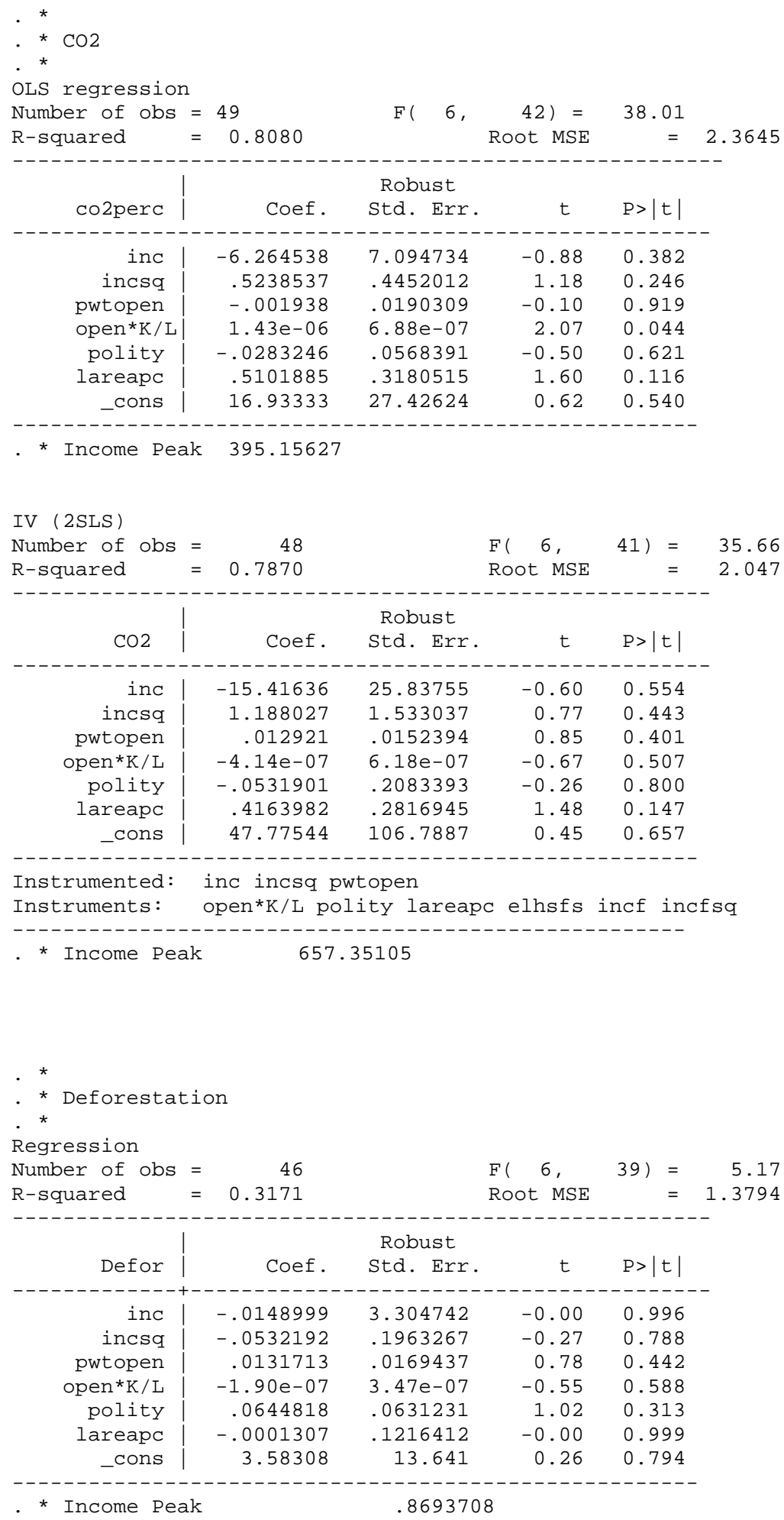




\begin{tabular}{|c|c|c|c|c|}
\hline $\begin{array}{l}\text { IV (2SLS) } \\
\text { Number of obs }= \\
\text { R-squared }\end{array}$ & $\begin{array}{r}46 \\
.\end{array}$ & & $\begin{array}{l}\text { F }(6, \\
\text { Root MSE }\end{array}$ & 39) $\begin{aligned} & = \\
& =\end{aligned}$ \\
\hline Defor & Coef. & $\begin{array}{l}\text { Robust } \\
\text { Std. Err. }\end{array}$ & t & $P>|t|$ \\
\hline inc & -55.94889 & 51.26357 & -1.09 & 0.282 \\
\hline incsq & 3.333191 & 3.060755 & 1.09 & 0.283 \\
\hline pwtopen & .0186028 & .0216911 & 0.86 & 0.396 \\
\hline open*K/L & $-1.89 e-06$ & $1.53 e-06$ & -1.23 & 0.225 \\
\hline polity & .4319458 & .4338433 & 1.00 & 0.326 \\
\hline lareapc & -.1944629 & .4228314 & -0.46 & 0.648 \\
\hline _cons & 230.9296 & 211.1499 & 1.09 & 0.281 \\
\hline
\end{tabular}

Instrumented: inc incsq pwtopen

Instruments: open*K/L polity lareapc elhsfs incf incfsq

. Income Peak 4414.692

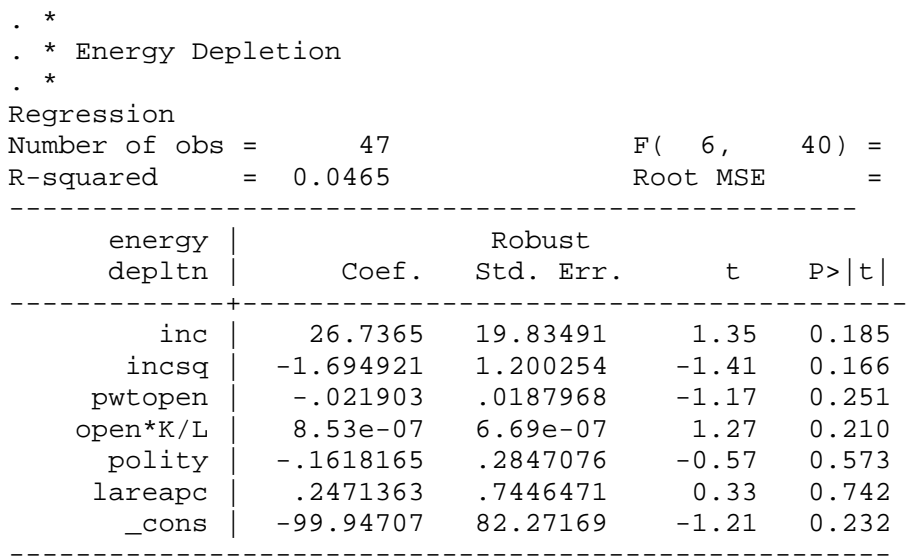

. * Income Peak 2663.0946

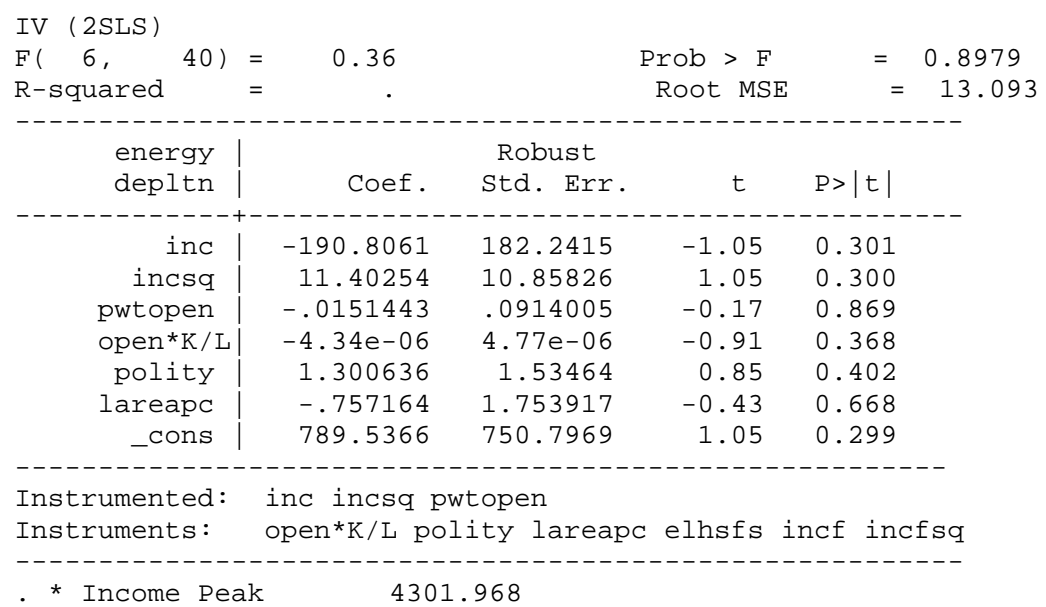




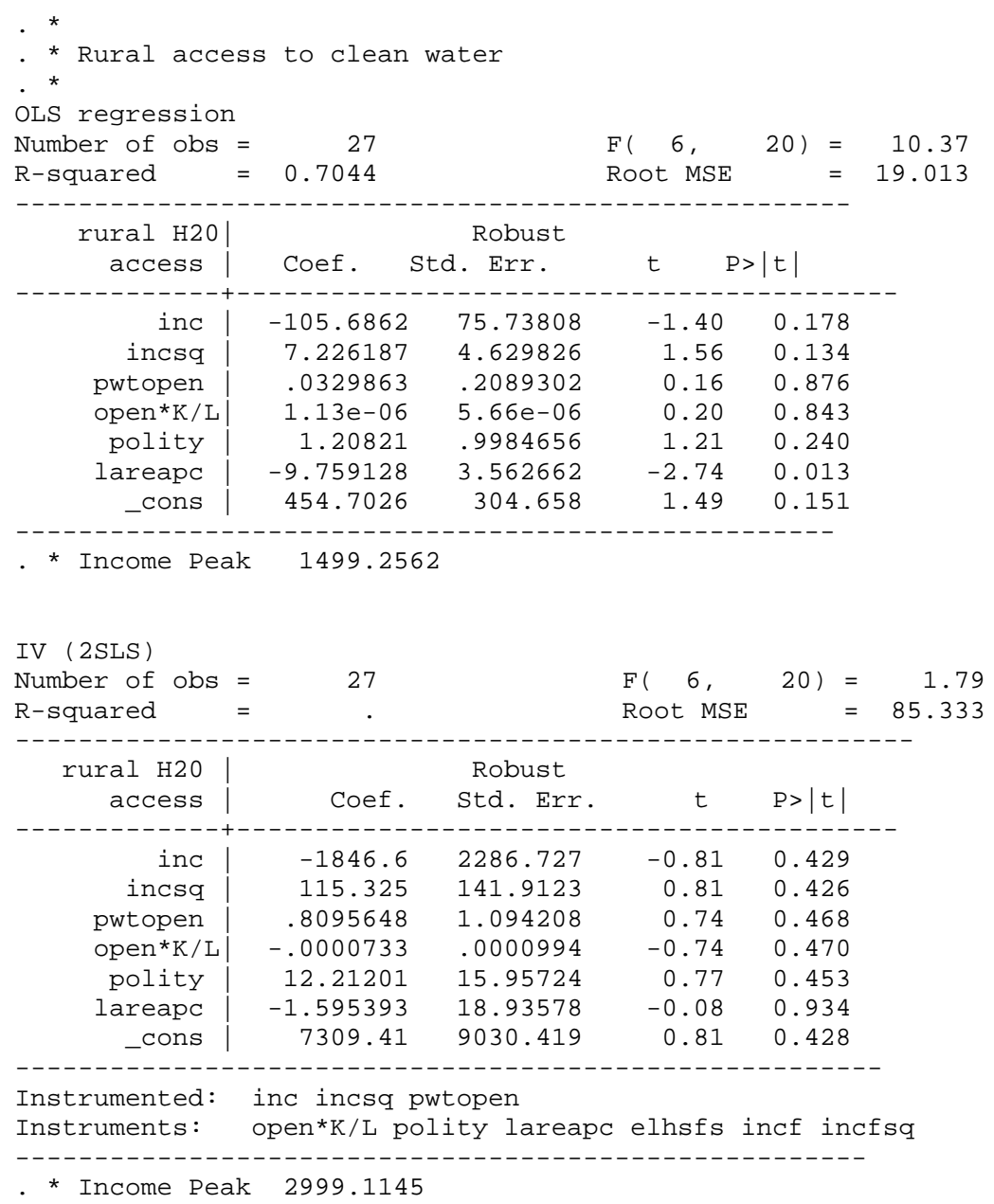




\section{Appendix}

\section{Tables A2 and A4: Environmental degradation equations (with income spline)}

. * Three-piece spline for real income per capita, split at the .33 and .66 percentiles.*

\section{OLS regressions}

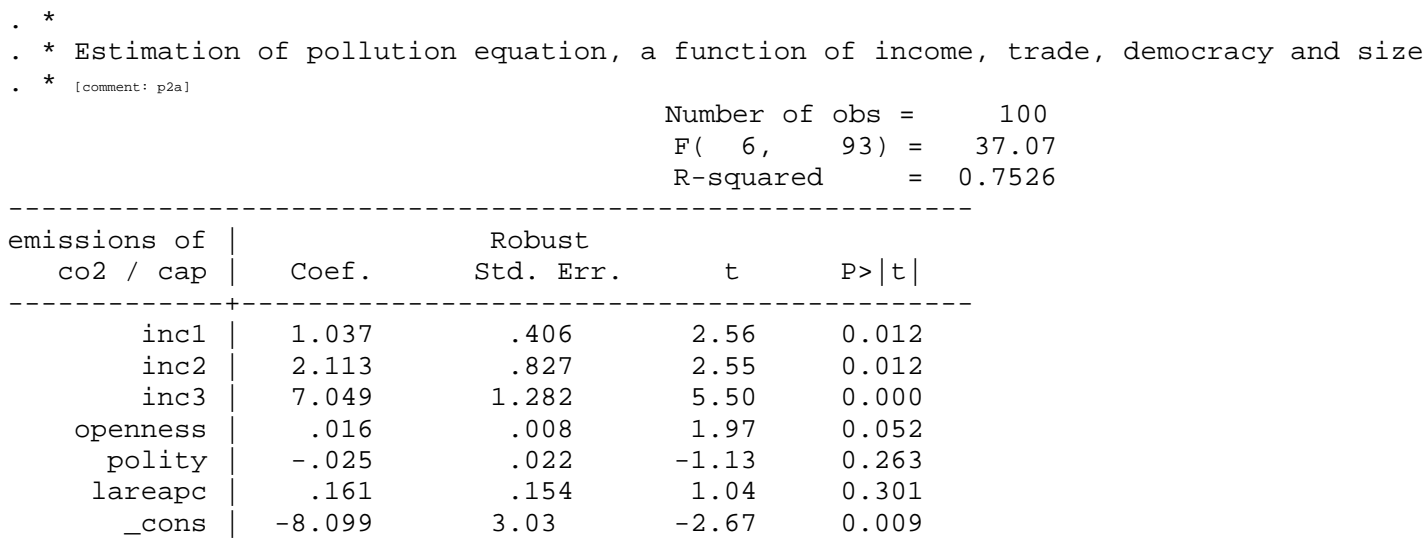

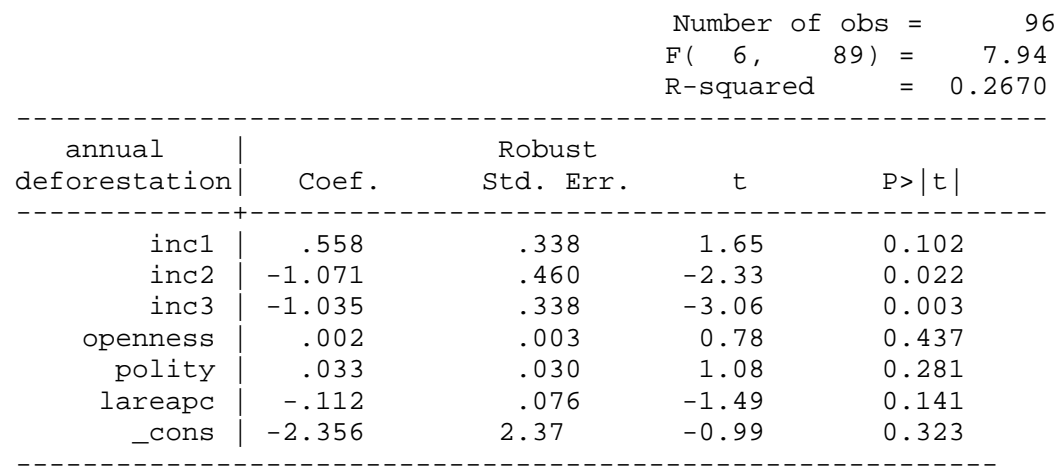

\begin{tabular}{|c|c|c|c|c|c|}
\hline & & & $\begin{array}{l}\text { Number of } \\
\text { F( } 6, \\
\text { R-squared }\end{array}$ & $\begin{array}{l}\text { obs }= \\
\begin{aligned}91) & = \\
& =\end{aligned}\end{array}$ & $\begin{array}{r}98 \\
3.07 \\
0.1653\end{array}$ \\
\hline $\begin{array}{c}\text { energy deple- } \\
\text { tion (\%GDP) }\end{array}$ & Coef. & $\begin{array}{l}\text { Robust } \\
\text { Std. Err. }\end{array}$ & t & $P>|t|$ & \\
\hline inc1 & 6.701 & 2.210 & 3.03 & 0.003 & \\
\hline inc2 & 4.288 & 2.902 & 1.48 & 0.143 & \\
\hline inc3 & -3.197 & 1.842 & -1.74 & 0.086 & \\
\hline openness & -.013 & .009 & -1.53 & 0.130 & \\
\hline polity & -.446 & .167 & -2.68 & 0.009 & \\
\hline lareapc & .249 & .419 & 0.59 & 0.554 & \\
\hline _cons & -45.384 & 15.583 & -2.91 & 0.005 & \\
\hline
\end{tabular}




\begin{tabular}{|c|c|c|c|c|c|}
\hline & & & $\begin{array}{l}\text { Number } \\
\text { F ( } 6, \\
\text { R-square }\end{array}$ & $\begin{aligned} \text { obs } & = \\
29) & = \\
& =\end{aligned}$ & $\begin{array}{r}36 \\
7.13 \\
0.2077\end{array}$ \\
\hline \multicolumn{6}{|c|}{ Robust } \\
\hline $\mathrm{NO}_{2}$ & Coef. & Std. Err. & t & \multicolumn{2}{|l|}{$P>|t|$} \\
\hline incl & -373.491 & 209.562 & -1.78 & 0.085 & \\
\hline inc2 & 169.749 & 57.176 & 2.97 & 0.006 & \\
\hline inc 3 & -19.707 & 14.786 & -1.33 & 0.193 & \\
\hline openness & -.302 & .159 & -1.91 & 0.066 & \\
\hline polity & -3.854 & .975 & -3.96 & 0.000 & \\
\hline lareapc & -5.897 & 6.055 & -0.97 & 0.338 & \\
\hline _cons & 2740.844 & 1499.377 & 1.83 & 0.078 & \\
\hline
\end{tabular}

\begin{tabular}{|c|c|c|c|c|}
\hline & & & $\begin{array}{l}\text { Number of ob } \\
\text { F( } 6, \\
\text { R-squared }\end{array}$ & $\begin{array}{rr}S= & 41 \\
= & 40.04 \\
= & 0.6789\end{array}$ \\
\hline & \multicolumn{4}{|c|}{ Robust } \\
\hline $\mathrm{SO}_{2}$ & Coef. & Std. Err. & t & $P>|t|$ \\
\hline inc1 & 46.351 & 68.589 & 0.68 & 0.504 \\
\hline inc2 & 29.202 & 17.0379 & 1.71 & 0.096 \\
\hline inc3 & -16.540 & 8.827 & -1.87 & 0.070 \\
\hline openness & -.303 & .082 & -3.72 & 0.001 \\
\hline polity & -6.561 & 2.081 & -3.15 & 0.003 \\
\hline lareapc & -3.223 & 1.398 & -2.30 & 0.027 \\
\hline _cons & -248.434 & 488.917 & -0.51 & 0.615 \\
\hline
\end{tabular}

- reg suspm inc1-inc3 openness polity lareapc, robust

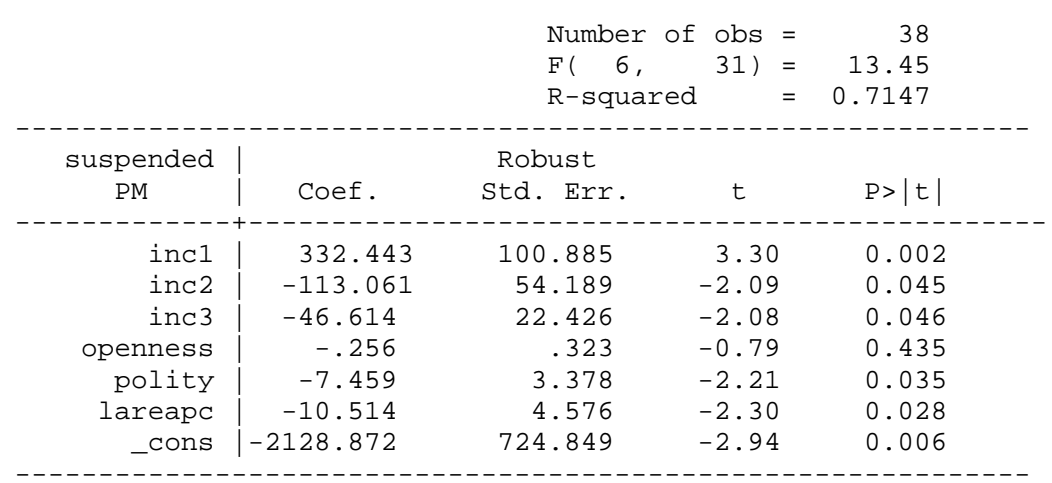


Table A3 and A5: Environmental degradation equations (with income spline)

\section{IV regressions}

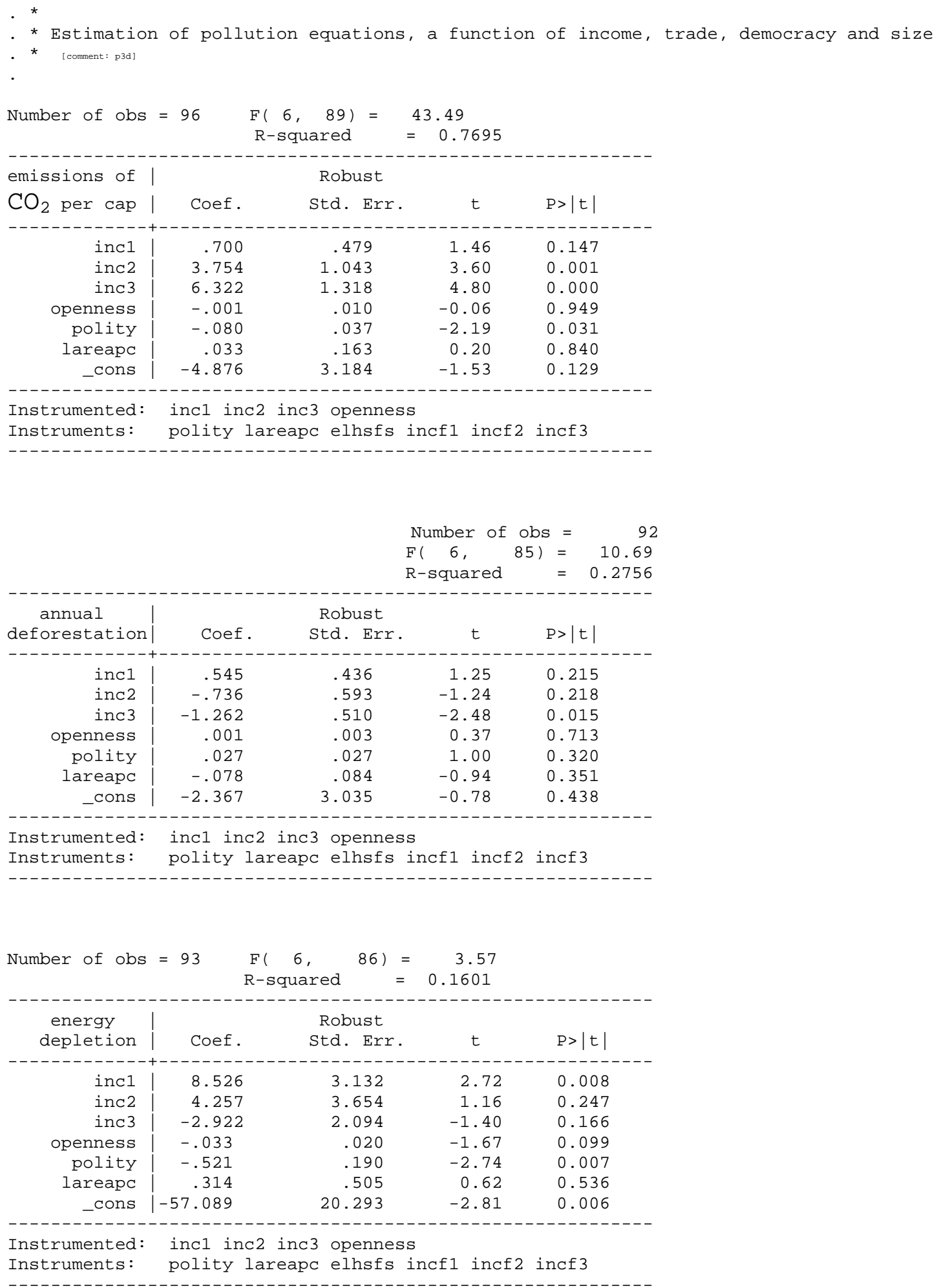




\begin{tabular}{|c|c|c|c|c|}
\hline & & Robust & & \\
\hline $\mathrm{NO}_{2}$ & Coef. & Std. Err. & $t$ & $P>|t|$ \\
\hline inc1 & -492.92 & 324.92 & -1.52 & 0.140 \\
\hline inc2 & 207.14 & 100.29 & 2.07 & 0.048 \\
\hline inc3 & -20.82 & 10.99 & -1.89 & 0.069 \\
\hline openness & -.324 & .186 & -1.75 & 0.092 \\
\hline polity & -4.448 & 1.216 & -3.66 & 0.001 \\
\hline lareapc & -5.792 & 6.445 & -0.90 & 0.376 \\
\hline _cons & 3593.957 & 2331.116 & 1.54 & 0.134 \\
\hline $\begin{array}{l}\text { Instrumented: } \\
\text { Instruments: }\end{array}$ & $\begin{array}{l}\text { inc1 inc2 } \\
\text { polity lar }\end{array}$ & $\begin{array}{l}\text { c3 opennes: } \\
\text { pc elhsfs }\end{array}$ & cfl inc & incf 3 \\
\hline
\end{tabular}

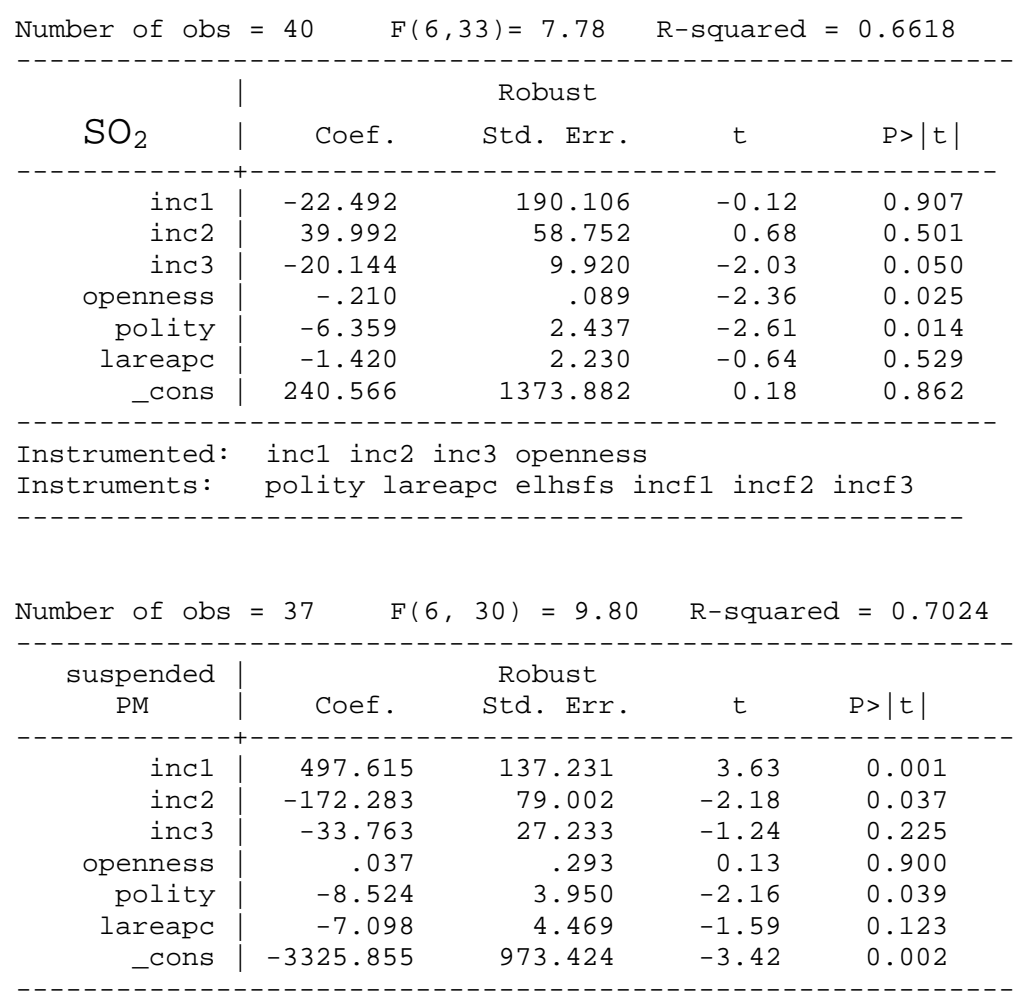

Instrumented: inc1 inc2 inc3 openness

Instruments: polity lareapc elhsfs incf1 incf2 incf3 